\title{
Wetland and Sensitive Species Survey Report for $Y$-12: Proposed Uranium Processing Facility (UPF)
}

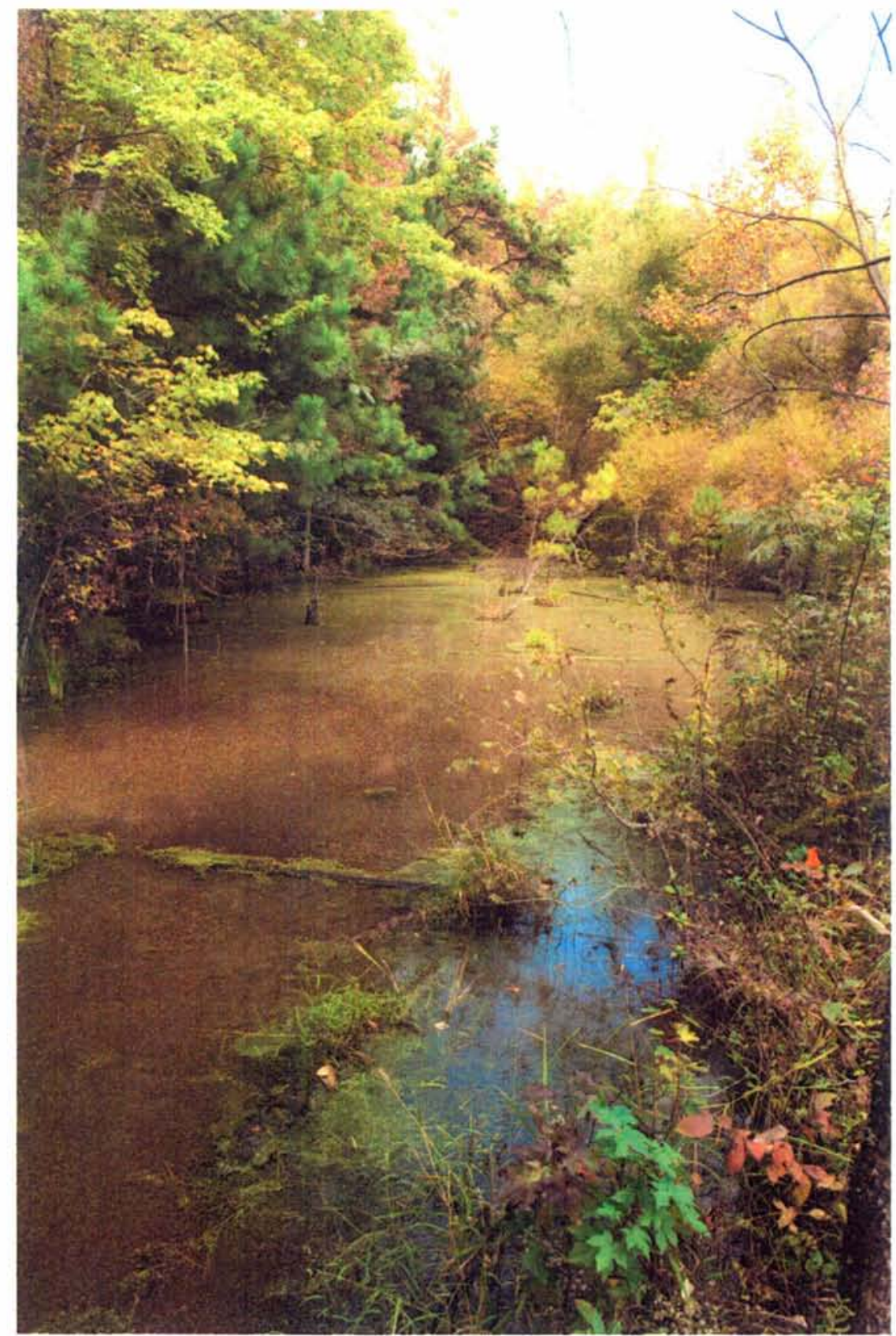

\section{RC-UPF DMC}

03-23-10P03:23 RCVD
This s-cument has been reviewed by a Y-12 DCl UCNI-RO and has been determined to be UNCLASSIFIED and contains no UCNI. This review does not constitute clearance for Public Release.

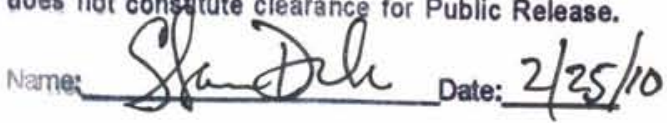

Neil Giffen

Mark Peterson

Scott Reasor Larry Pounds Greg Byrd 


\title{
DOCUMENT AVAILABILITY
}

Reports produced after January 1, 1996, are generally available free via the U.S. Department of Energy (DOE) Information Bridge.

Web site http://www.osti.gov/bridge

Reports produced before January 1,1996 , may be purchased by members of the public from the following source

\author{
National Technical Information Service \\ 5285 Port Royal Road \\ Springfield. VA 22161 \\ Telephone 703-605-6000 (1-800-553-6847) \\ TDD 703-487-4639 \\ Fax 703-605-6900 \\ E-mail info@ntis.fedworld.gov \\ Web site http://www.ntis.gov/support/ordernowabout.htm
}

Reports are available to DOE employees, DOE contractors, Energy Technology Data Exchange (ETDE) representatives, and International Nuclear Information System (INIS) representatives from the following source.

Office of Scientific and Technical Information

P.O. Box 62

Oak Ridge, TN 37831

Telephone 865-576-8401

Fax 865-576-5728

E-mail reports@adonis.osti.gov

Web site http://www.osti.gov/contact.html

This report was prepared as an account of work sponsored by an
agency of the United States Government. Neither the United States
Government nor any agency thereof, nor any of their employees.
makes any warranty, express or implied, or assumes any legal
liability or responsibility for the accuracy, completeness, or
usefulness of any information, apparatus, product, or process
disclosed, or represents that its use would not infringe privately
owned rights. Reference herein to any specific commercial product,
process, or service by trade name, trademark, manufacturer, or
otherwise, does not necessarily constitute or imply its endorsement,
recommendation, or favoring by the United States Government or
any agency thereof. The views and opinions of authors expressed
herein do not necessarily state or reflect those of the United States
Government or any agency thereof.




\title{
WETLAND AND SENSITIVE SPECIES SURVEY REPORT FOR Y-12: PROPOSED URANIUM PROCESSING FACILITY (UPF)
}

\author{
Neil Giffen' \\ Mark Peterson' \\ Scott Reasor ${ }^{3}$ \\ Larry Pounds ${ }^{2}$ \\ Greg Byrd ${ }^{2}$ \\ ${ }^{1}$ Environmental Sciences Division \\ ${ }^{2}$ Facilities and Operations Directorate \\ Oak Ridge National Laboratory \\ ${ }^{3}$ Oak Ridge Institute for Science and Education
}

November 2009

\author{
Prepared for \\ Mick Wiest \\ Clarence Hill \\ Environmental Compliance Department \\ Y-12 National Security Complex
}

Prepared by

OAK RIDGE NATIONAL LABORATORY

Oak Ridge, Tennessee 37831

managed by

UT-BATTELLE, LLC

for the

U.S. DEPARTMENT OF ENERGY

under contract DE-AC05-00OR22725 


$$
\text { - }
$$




\section{CONTENTS}

\section{Page}

LIST OF FIGURES

.. $\mathrm{V}$

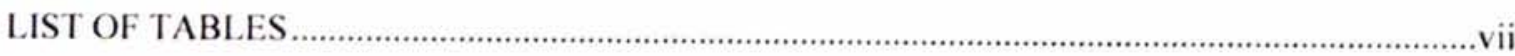

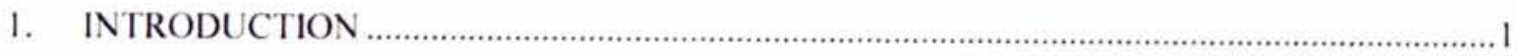

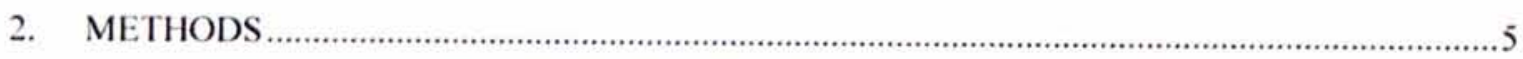

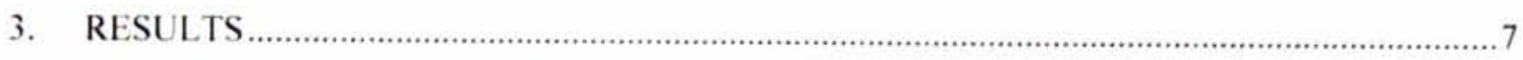

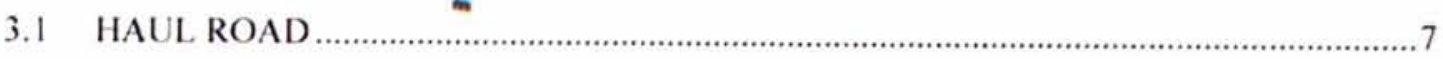

3.1.1 West End Haul Road Corridor - New Salvage Yard to Wetland \#1 ......................

3.1.2 East End Haul Road Corridor - East of Wetland \#I to Polaris Parking Lot

3.2 WET SOILS DISPOSAL AREA ….........................................................................

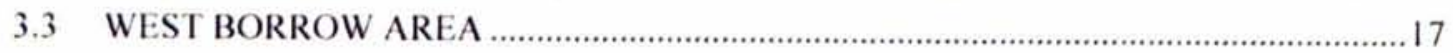

3.4 ADDITIONAL AREAS OF STUDY - POND NORTHEAST OF BUILDING 9114

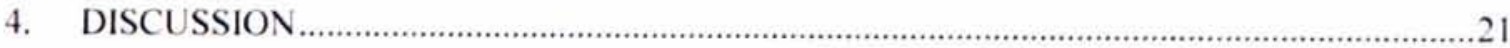

4.I WEST END HAUL ROAD CORRIDOR - NEW SALVAGE YARD TO WETLAND\#I.

4.2 EAST END HAUL ROAD CORRIDOR - EAST OF WETLAND \#I TO

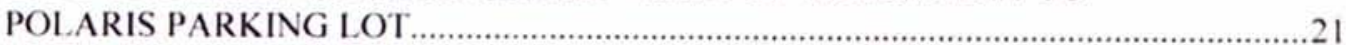

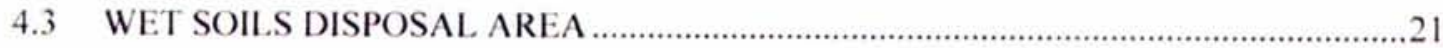

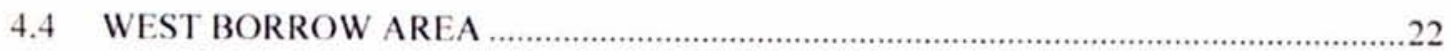

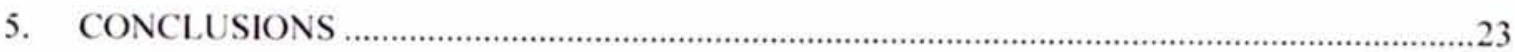

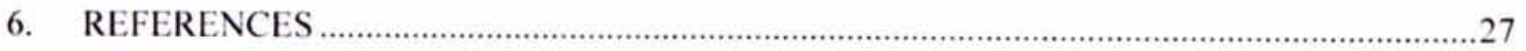

Appendix A. CREDENTIALS AND QUALIFICATIONS .............................................................29

Appendix B. REPRESENTATIVE WETLAND DELINEATION REPORTS ..................................33

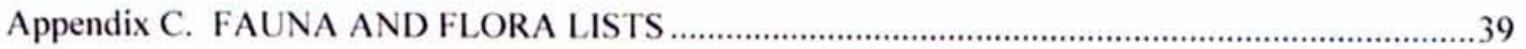


(TIIIS PAGE IEFT BI.ANK INTENTIONAIIYY) 


\section{LIST OF FIGURES}

Page

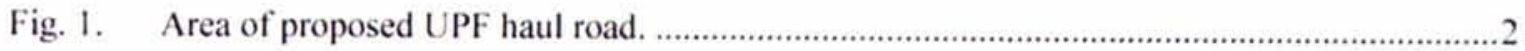

Fig. 2. Area of proposed UPF Wet Soils and Dry Soils (West Borrow Area) Disposal Areas...........3

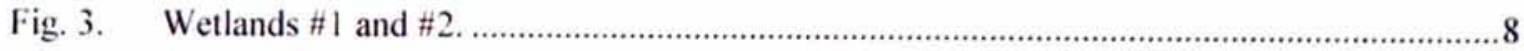

Fig. 4. West end haul road corridor........................................................................................ 10

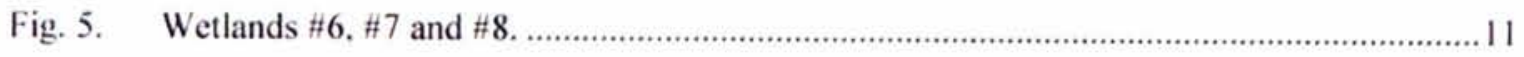

Fig. 6. East end haul road corridor area. ............................................................................. 12

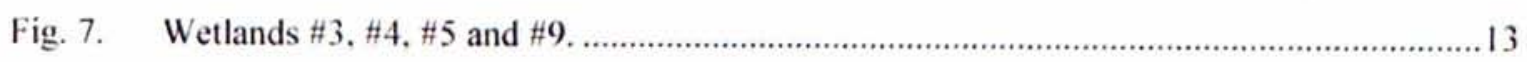

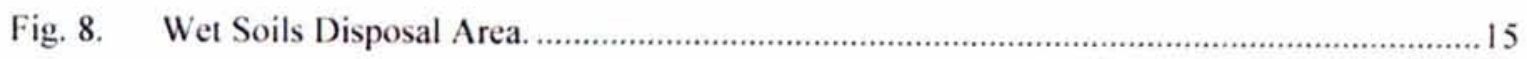

Fig. 9. Blue line streams in vicinity of Wet Soils Disposal Area. ............................................ 6

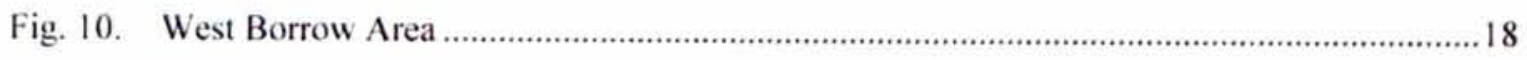




$$
\text { - }
$$




\section{LIST OF TABLES}

\section{Page}

Table 1. Wetland size and type for the UPF project ............................................................14

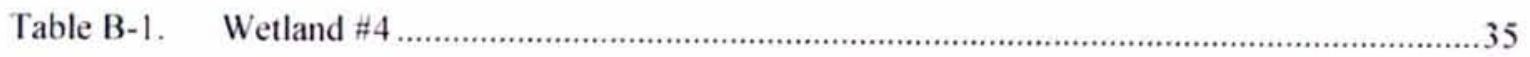

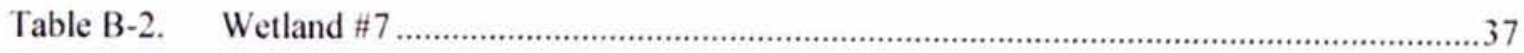

Table C-1. Bird species list - haul road corridor ....................................................................

Table C-2. Reptile and amphibian species list - haul road corridor ............................................43

Table C-3. Plant species list for the haul road corridor ..............................................................44

Table C-4. Bird species list - Wet Soils Disposal Area ..............................................................47

Table C-5. Plant species list for the Wet Soils Disposal Area ....................................................48

Table C-6. Bird species list - West Borrow Area ..........................................................................50

Table C-7. Plant species list for West Borrow Area ...................................................................

Table C-8. Plant species list for the pond and adjacent areas near Building $9114 \ldots \ldots \ldots \ldots \ldots \ldots \ldots . . . . . . .53$ 


\section{(TIIIS PAGE ILET BI.ANK INTENTIONALI.Y)}




\section{INTRODUCTION}

This report summarizes the results of an environmental survey conducted at sites associated with the proposed Uranium Processing Facility (UPF) at the Y-12 National Security Complex in SeptemberOctober 2009. The survey was conducted in order to evaluate potential impacts of the overall project. This project includes the construction of a haul road, concrete batch plant, wet soil storage area and dry soil storage area. The environmental surveys were conducted by natural resource experts at ORNL who routinely assess the significance of various project activities on the Oak Ridge Reservation (ORR). Natural resource staff assistance on this project included the collection of environmental information that can aid in project location decisions that minimize impacts to sensitive resources such as significant wildlife populations, rare plants and wetlands. Natural resources work was conducted in various habitats, corresponding to the proposed areas of impact. The credentials/qualifications of the researchers are contained in Appendix A.

The proposed haul road traverses a number of different habitats including a power-line right-of-way, wetlands, streams, forest and mowed areas. It extends from what is known as the New Salvage Yard on the west to the Polaris Parking Lot on the east. This haul road is meant to connect the proposed concrete batch plant to the UPF building site. The proposed site of the concrete batch plant itself is a highly disturbed fenced area. This area of the project is shown in Fig. 1.

The proposed Wet Soils Disposal Area is located on the north side of Bear Creek Road at the former Control Burn Study Area. This is a second growth area containing thick vegetation, and extensive dead and down woody material. This area of the project is shown in Fig. 2.

The dry soils storage area is proposed for what is currently known as the West Borrow Area. This site is located on the west side of Reeves Road south of Bear Creek Road. The site is an early successional field. This area of the project is shown in Fig. 2. 
(THIS PAGE LEFT BLANK INTENTIONALLYY) 


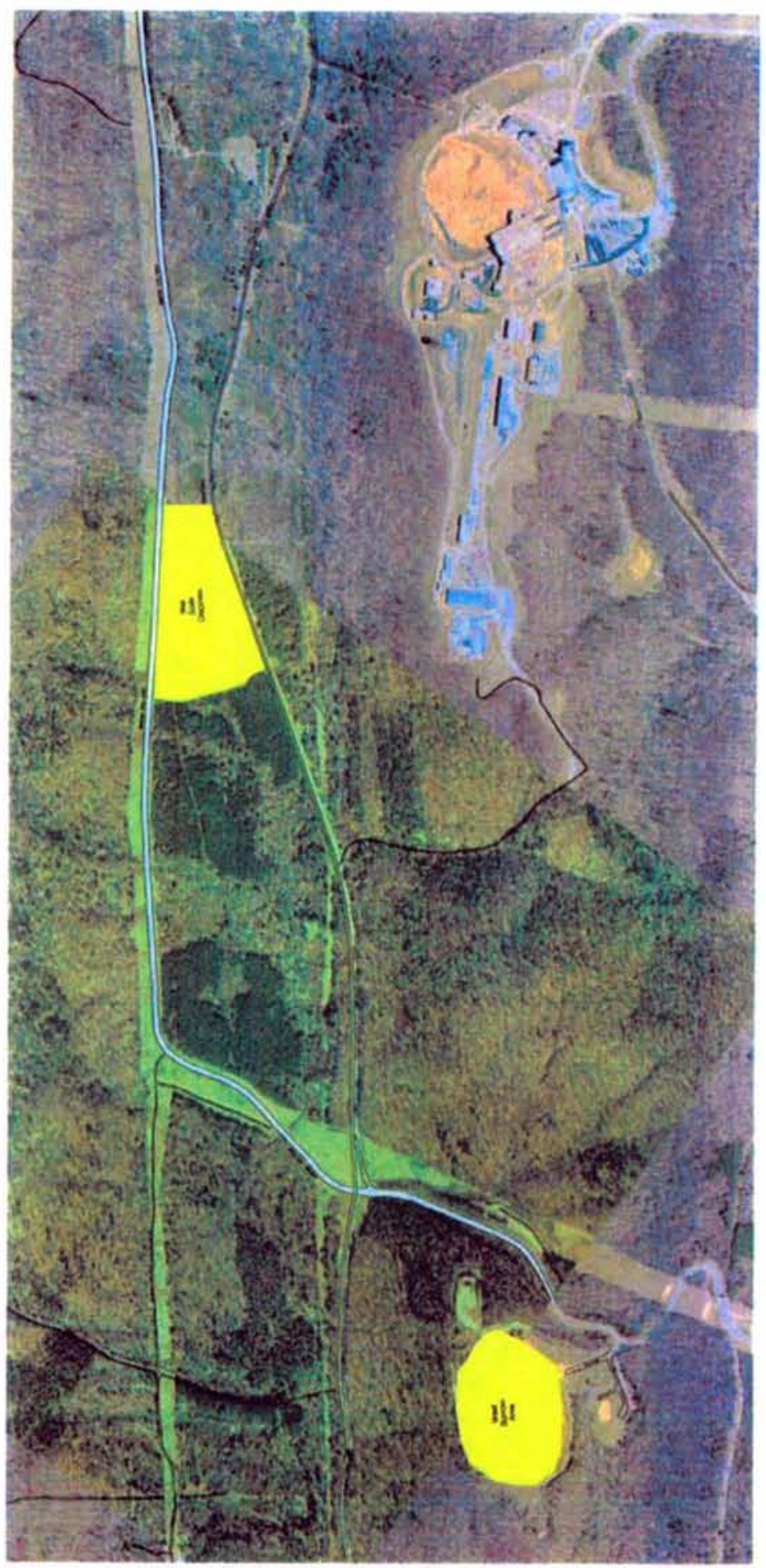

Fig. 2. Area of proposed UPF Wet Soils and Dry Soils (West Borrow Area) Disposal Areas. 
(TIIIS PAGE LEFT BL.ANK INTENTIONALIY) 


\section{METHODS}

The following is a brief description of the methods used during the study.

Bird Survey - A series of transect surveys of site habitats were conducted during the morning hours. During that time all birds either heard or seen were recorded. Incidental encounters with birds were also recorded during surveys of other natural resources. In addition, any sign (e.g., woodpecker drillings) was noted where it could be identified to species.

Small Mammal Survey - Small mammal surveys were conducted at the site using Sherman live traps. A total of 114 traps were set out on the site covering all habitats. Small mammals were trapped for a total of 17 nights during a two week period. This is equal to a total of 1938 trap nights ( 17 nights $\mathrm{x}$ 114 traps). All captured small mammals were identified and released at the location of capture. Incidental encounters with mammals were also recorded during surveys of other natural resources.

Reptile and Amphibian Survey - One day visual encounter surveys (VES) were conducted in all site habitats. This involved searching under logs, rocks, bark, leaf litter and other debris. All reptiles and amphibians encountered were identified and recorded. Incidental encounters with reptiles and amphibians were also recorded during surveys of other natural resources. Minnow traps were set and dip netting was conducted in wetlands with sufficient water, for the capture of amphibian species.

Vegetation Survey - Walk-through surveys of each habitat were conducted at which time all vascular plant species that could be identified were recorded. Additional surveys were conducted with a professional plant ecologist to specifically identify rare plants. A visual survey of trees was conducted on the site to determine the presence of potential bat roosting habitat.

Wetlands Survey - Wetlands are considered of high ecological value; consequently, destruction or loss of wetlands, as well as major disturbance such as dredging or filling of wetlands, is regulated by both federal and state agencies. Wetlands associated with the UPF project were determined and delineated per Army Corps of Engineers' wetland delineation protocols (ACOE, 1987). To be considered a jurisdictional wetland, a site must meet the necessary hydrology, soils, and wetland-vegetation criteria. For each wetland plant community type, the dominant plant species and their abundance were noted. and bore holes were dug to evaluate and characterize the soils and hydrology of the site. Wetland locations were mapped with a high accuracy Trimble GPS unit and accompanying software.

The wetland vegetation criterion is met if more than 50 percent of the dominant species within each stratum (trees, shrubs, woody vines, herbs) are hydrophytic. To make this determination, species are assigned an indicator status based on the USFWS National List of Plant Species that Occur in Wetlands: 1988 National Summary (Reed 1988). The indicator species status codes are: obligate wetland (OBL), facultative wetland (FACW), facultative (FAC), facultative upland (FACU), and upland (UPL). A plus (+) or minus (-) sign following the indicator code denotes a tendency towards the wetter (+) or drier (-) end of the scale. For classifying an area as hydrophytic, the dominant plant species in each stratum must have the following vegetation species codes: $\mathrm{OBL}, \mathrm{FACW}+, \mathrm{FACW}$, FACW-, FAC+, or FAC. Indicator definitions, as defined by the U.S. Fish and Wildlife Service, are:

Obligate Wetland $(\mathrm{OBL}$ ). Occur almost always (estimated probability $>99 \%$ ) under natural conditions in wetlands. 
Facultative Wetland (FACW). Usually occur in wetlands (estimated probability 67\%-99\%), but occasionally found in non-wetlands.

Facultative (FAC). Equally likely to occur in wetlands or non-wetlands (estimated probability $34 \%-66 \%$ ).

Facultative Upland (FACU). Usually occur in non-wetlands (estimated probability $67 \%-99 \%$ ), but occasionally found in wetlands (estimated probability $1 \%-33 \%$ ).

Obligate Upland (UPL). Occur in wetlands in another region, but occur almost always (estimated probability $>99 \%$ ) under natural conditions in non-wetlands.

Soil samples were extracted at multiple locations using a post-hole shovel to characterize the wetland sites and to assist in determining appropriate wetland boundaries. Each soil sample was examined for soil color and texture and reported per Munsell Company (1994) designations. The presence of mottles, manganese concretions, high organic content, and other indicators of hydric soil status was also examined.

The sites were examined for primary and secondary indicators of wetland hydrology. The presence and depth of surface water, as well as the soil saturation and depth to free water in the soil-boring hole was evaluated. The presence of watermarks, drift lines, oxidized root channels, water-stained leaves, and other indicators of wetland hydrology were also noted.

Representative determination reports are provided in Appendix B. 


\section{RESULTS}

The results of the natural resources surveys are presented by area.

\subsection{HAUL ROAD}

The haul road traverses a series of rolling hills with some steep slopes. The western portion of the proposed haul road site travels along a power line corridor bordered on the north and south by forested areas. The corridor itself in this area contains old field habitat with a mixture of shrubs and herbaceous vegetation. This portion of the proposed haul road also contains five wetland areas, as well as streams. The eastern portion of the proposed haul road traverses mainly mowed grassy areas that contain four wetland areas.

Bird Survey Results - A total of 23 bird species were identified along the haul road by sight or song.

There were 6 species recorded at the site that are on the Partners In Flight (PIF) list as being of regional importance in the ridge and valley. PIF monitors population trends based on data gathered throughout the region and lists those species that are in apparent decline. Generally, the most sensitive species are those impacted by forest fragmentation (i.e., interior forest species). Species in this category that were noted along the proposed haul road corridor are downy woodpecker (Picoides pubescens), eastern-wood pewee (Contopus virens) and Carolina chickadee (Poecile carolinensis). Other forest birds of note recorded on the site are the yellow-billed cuckoo (Coccyzus americanus), eastern screech-owl (Otus asio), hairy woodpecker (Picoides villosus) and pileated woodpecker (Dryocopus pileatus). The belted kingfisher (Ceryle alcyon) is another notable species on the PIF list. This bird species frequents ponds with preferred prey items and was recorded at Wetland \#I (Fig. 3) where tadpoles and adult frogs are abundant. The remaining PIF listed birds found on the site are those common to edge and old field habitats. A complete bird list for the haul road is contained in Appendix C - Table C-I.

Small Mammal Survey Results - A total of 64 Sherman live traps were set out along the haul road corridor. Small mammals were trapped for a total of 7 nights. This is equal to a total of 448 trap nights ( 7 nights $\times 64$ traps).

White-footed mouse (Peromyscus leucopus) and hispid cotton rat (Sigmodon hispidus) were the only species of small mammals captured in traps along the haul road corridor. White-tailed deer (Odocoileus virginianus) and striped skunk (Mephitis mephitis) were also recorded incidentally while conducting other surveys. Sign of coyote (Canis latrans) (tracks) was also noted.

Reptile and Amphibian Survey - A one day VES was conducted along the haul road corridor. This involved searching under logs, rocks, bark, leaf litter and other debris. All reptiles and amphibians found were recorded. Dip nets and minnow traps were used for sampling in wetlands with sufficient water. Incidental encounters with reptiles and amphibians were also recorded during surveys of other natural resources. A complete list of reptiles and amphibians recorded during the survey is contained in Appendix C - Table C-2.

Wetlands along the haul road corridor provide important habitat for amphibian species. Of particular note are Wetlands $\# 1$ and $\# 2$ (Fig. 3 ). Wetland $\# 1$ has a large pond that supports a good population of red-spotted newts (Notophthalmus viridescens viridescens) and several anuran (frog) species. Wetland 
$\# 2$ has a pond at its west end that also supports a good population of red-spotted newts and larval marble salamanders (Ambystoma opacum).

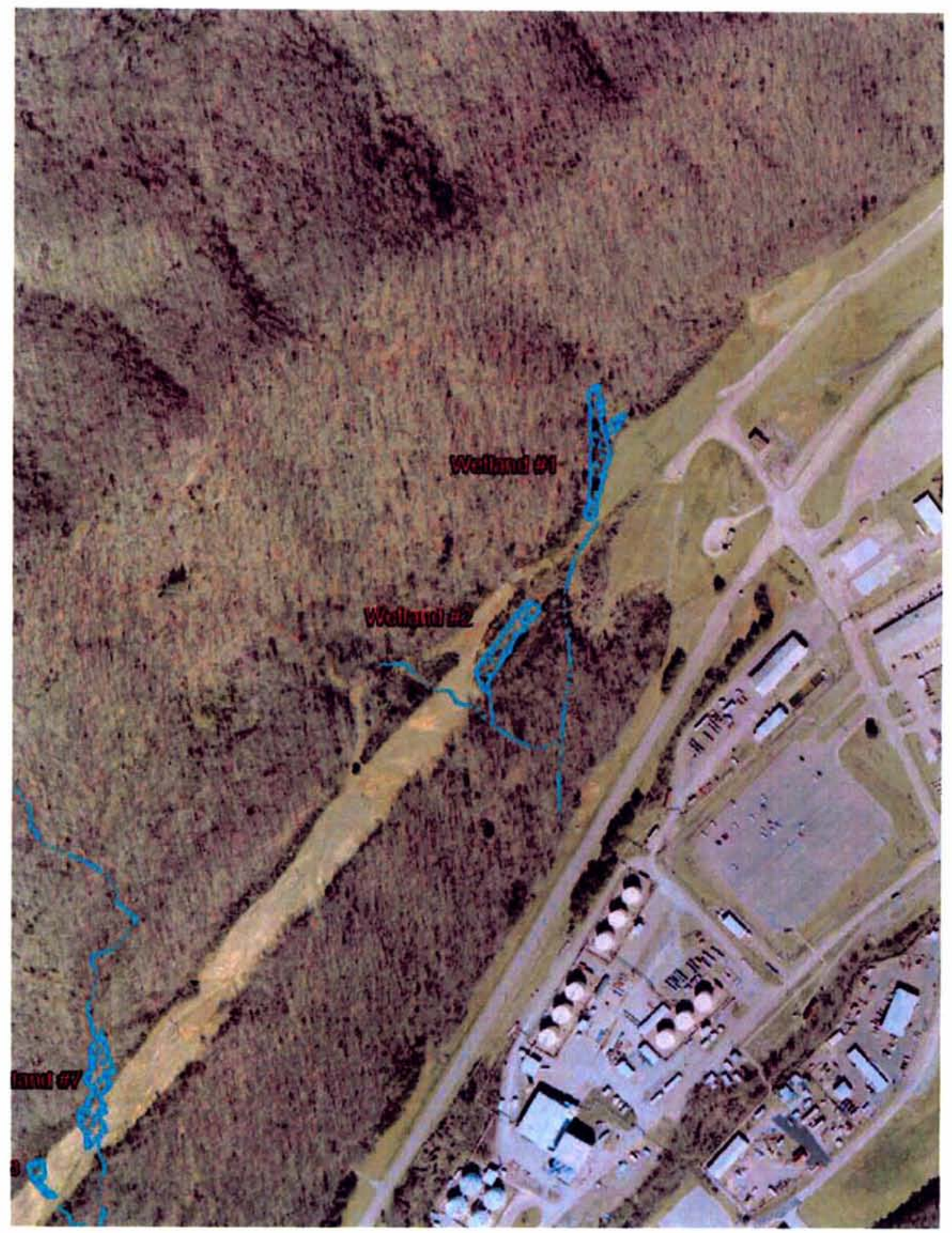

Fig. 3. Wetlands $\# 1$ and $\# 2$. 
Vegetation Survey - A one day walk-through was conducted at which time all vascular plant species that could be identified were recorded. An additional survey was conducted with a professional plant ecologist to specifically identify rare plants. The haul road corridor consists of a mixture of old field and mowed turf grass areas, along with some small areas of forest and wetlands. No protected plant species were observed along the haul road corridor. A complete list of plant species recorded along the haul road corridor is contained in Appendix C - Table C-3.

\subsubsection{West End Haul Road Corridor - New Salvage Yard to Wetland \#1}

The western end of the haul road corridor extending from the New Salvage Yard to Wetland \# 1 includes old field habitat, forest and five scattered wetlands. Figure 4 shows a portion of this area.

The old field habitat is contained within the existing power-line corridor. In this corridor are scattered shrubs and herbaceous vegetation. Common shrubs in this area include smooth sumac (Rhus glabra). winged sumac (Rhus copallina) and eastern red cedar (Juniperus virginiana). Also in this area of the power-line corridor are sweetgum (Liquidamber styraciflua), tulip poplar (Liriodendron tulipifera) and black willow (Salix nigra) saplings. Blackberry (Rubus sp) ) and Japanese honeysuckle (Lonicera japonica) are also prevalent in this area. Herbaceous species include goldenrods, other wildflowers and grasses.

The forest habitat in this area is characterized by an overstory that includes white oak (Quercus alba). southern red oak (Quercus falcata), chestnut oak (Quercus montana), tulip poplar, red maple (Acer rubrum) and sweetgum. The understory is relatively open and contains saplings of several different species, including American beech (Fagus grandifolia), red maple, sweetgum, southern red oak and pignut hickory (Carya glabra). Also in the understory are flowering dogwood (Cornus florida). sourwood (Oxydendrum arboretum), black cherry (Prunus serotina), common pawpaw (Asimina triloba) and lowbush blueberry (Vaccinium pallidum). Groundcover in the area is also scattered, and includes Virginia creeper (Parthenocissus quinquefolia), Christmas fern (Polystichum acrostichoides), lady fern (Athyrium filix-femina), poison ivy (Toxicodendron radicans), muscadine (Vitis rotundifolia) and striped pipsissewa (Chimaphila maculata). Herbaceous growth includes horse-balm (Collinsonia canadensis), Nepal grass (Microstegium vimineum), beefsteak plant (Perilla frutescens), downy rattlesnake plantain (Goodyera pubescens) and little brown jug (Hexastylis arifolia). Of note where the haul road cuts north out of the power-line right-of-way into the forested area are white oaks with exfoliating bark. These trees provide potential roosting habitat for the federally endangered Indiana bat (Myotis sodalis). Indiana bats utilize such trees for maternity roosts from approximately mid-May through mid-September. The ORR is within the known range of the Indiana bat (Harvey et. al. 1999).

A small constricted wetland ( $\# 6$ ) is present at the west end of the site on the power-line corridor near the New Salvage Yard Road (Fig. 5). This wetland is approximately 0.06 acres in size. The wetland contains black willow and some common alder (Alnus serrulata) in the overstory. Herbaceous vegetation in this wetland includes rice cutgrass (Leersia oryzoides), leafy bulrush (Scirpus polyphyllus), tearthumb (Polygonum sagittatum), orange jewelweed (Impatiens capensis), soft rush (Juncus effusus), small-spike false-nettle (Boehmeria cylindrica) and dotted smartweed (Polygonum punctatum).

Just northeast of Wetland \#6 along the power-line right-of-way is Wetland \#8 (Fig. 5). This wetland is approximately 0.06 acres in size. This is a constricted wetland with an intermittent stream that flows out of the south end across the right-of-way into the adjacent forested area. This wetland is dominated by tearthumb, with some Juncus sp. and Cyperus sp. 


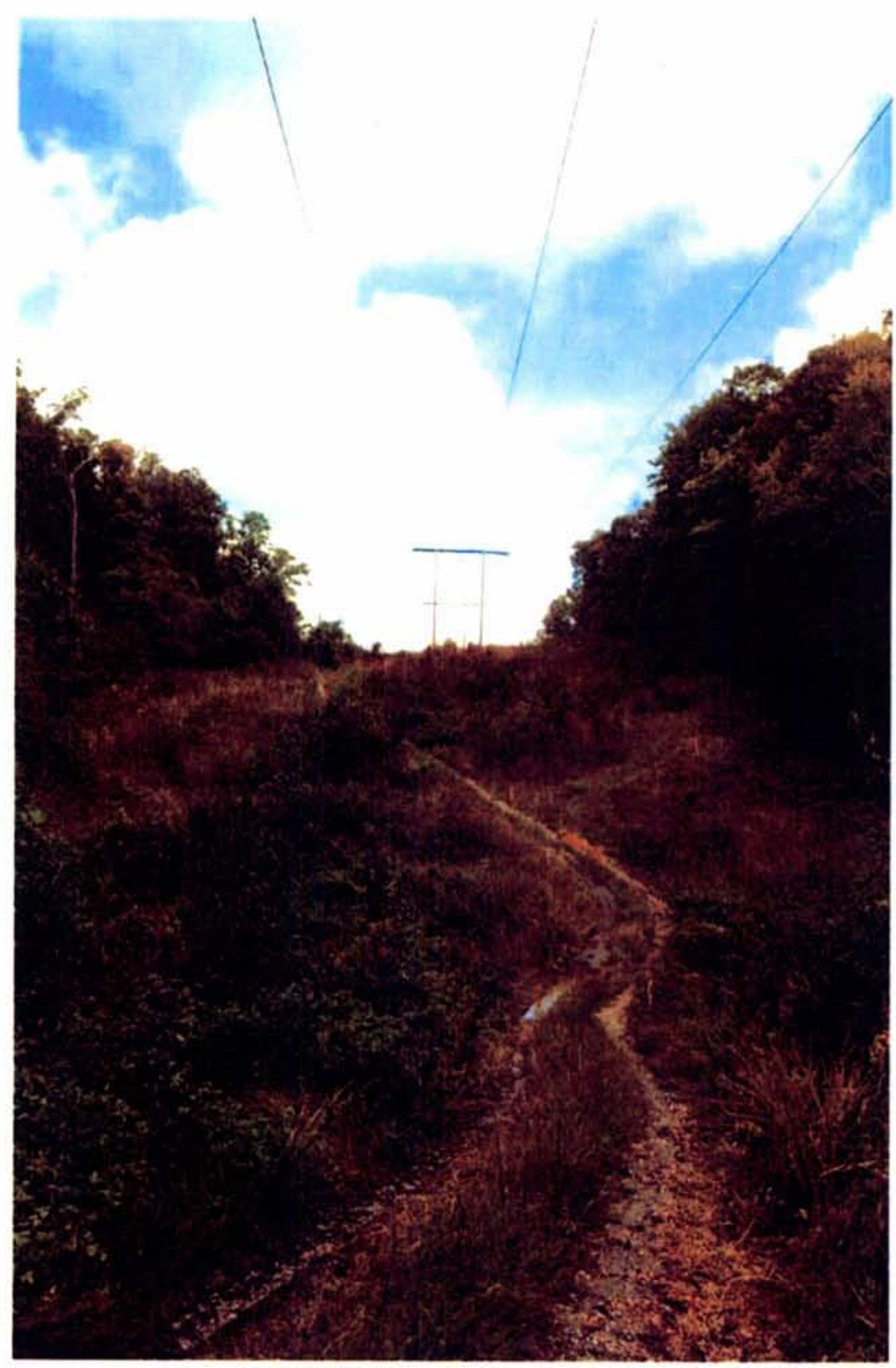

Fig. 4. West end haul road corridor.

A more extensive wetland system (Wetland \#7) exists further along the power-line right-of-way (Fig. $5)$. This wetland is approximately 0.32 acres in size. The boundaries of this wetland include a portion of the power-line right-of-way, as well as the forested area to the north. The power-line portion of this wetland includes a fairly diverse assemblage of herbaceous species, including leafy bulrush, tearthumb, rice cutgrass, orange jewelweed, horse-balm, and cardinal flower (Lobelia cardinalis). This area of the wetland also includes scattered common alders and black willows. The forested portion of the wetland is dominated by common alder, with some red maple and American sycamore (Platanus occidentalis). An intermittent stream flows into the northern end of the wetland off of Pine Ridge. The stream corridor continues out the south end of the wetland and through the forested area. It actually connects to an intermittent stream that flows southward out of Wetland $\# \mathbf{8}$. 


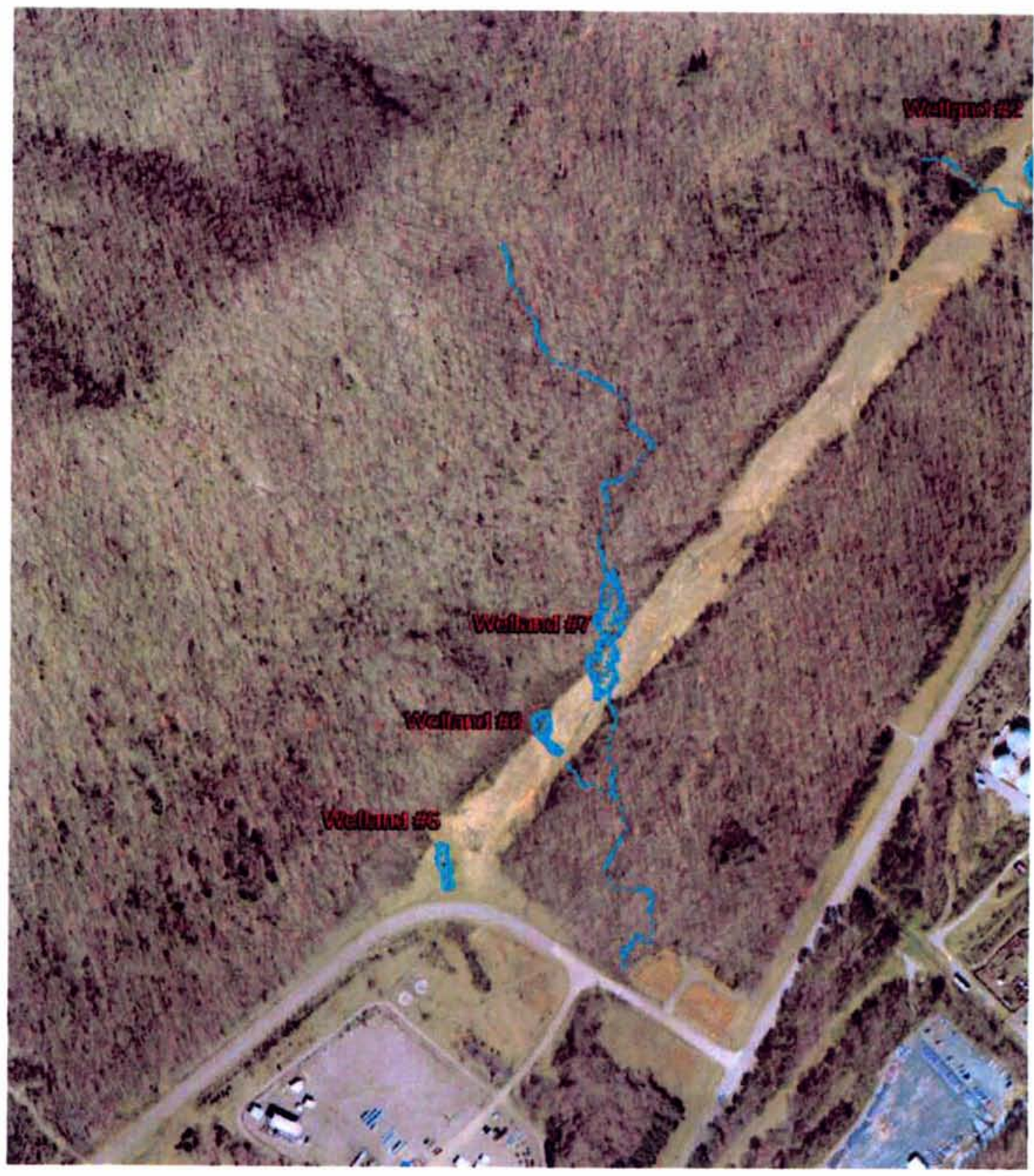

Fig. 5. Wetlands \#6, \#7 and \#8.

Wetland $\# 2$ is a rectangular wetland located just south of the proposed haul road route (Fig. 3 ). This wetland has a ponded area at its west end. The wetland is approximately 0.24 acres in size. Much of this wetland is dominated by tearthumb. Other plants in this wetland include cattail (Typha sp.), longbeaked arrow-head (Sagittaria australis), rice cutgrass, umbrella sedge (Cyperus strigosus), beak-rush (Rhyncospora sp.), blunt spikerush (Eleocharis obtusa) and narrow-leaved sunflower (Helianthus angustifolius). Flow out of the southwestern end of this wetland connects to an existing drainage that crosses the power-line to west of this area and into the forest. 
Wetland \#1 is northeast of Wetland \#2 (Fig. 3). This wetland consists of a large ponded area with wetland plant species on its fringes. The wetland is approximately 0.30 acres in size. Most of the wetland plants are concentrated on the south end of the pond and include small carpgrass (Arthraxon hispidus), rice cutgrass, cattail and long-beaked arrow-head. The northernmost end of the wetland includes a forested area. An intermittent stream flows out of the south end of the wetland and runs to the west into a large kudzu (Pueraria lobata) patch.

No rare plant species were found during the survey of this area.

\subsubsection{East End Haul Road Corridor - East of Wetland \#1 to Polaris Parking Lot}

The eastern end of the haul road corridor extending from east of Wetland \#1 to the Polaris Parking Lot includes mowed areas, four wetlands, limited early successional old field, and some forest. Figure 6 shows a portion of this area.

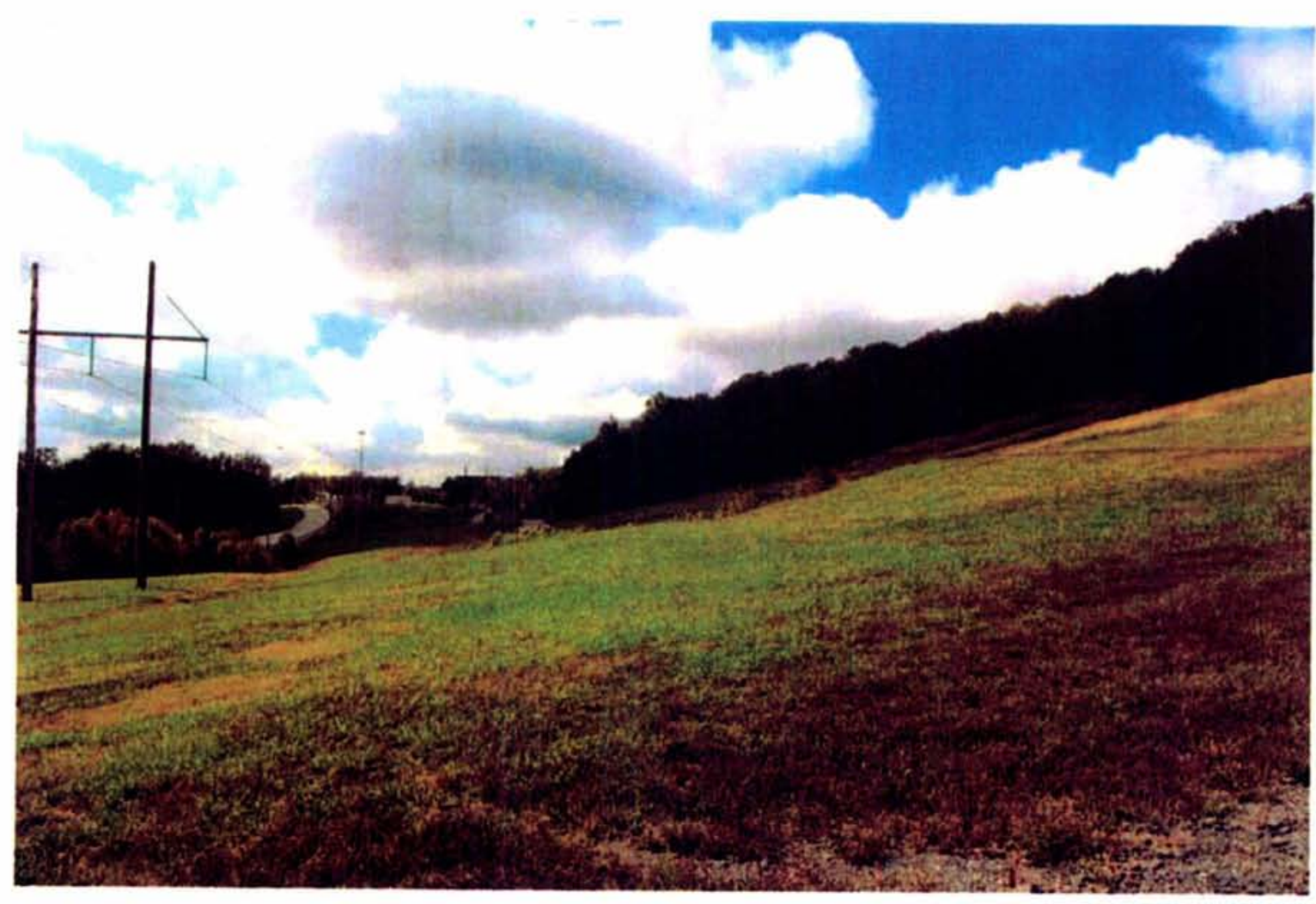

Fig. 6. East end haul road corridor area.

The majority of the proposed haul road in this area traverses the large mowed areas that contain fescue (Festuca sp.) and other turf species. There are also a limited number of rarely mowed areas.

Fingers of forest extend down off of Pine Ridge into the area of the proposed haul road corridor. These are mainly younger forested areas. Tree species include chestnut oak, white oak, red oaks (Quercus sp.), red maple, sweetgum, tulip poplar, pignut hickory and black gum (Nyssa sylvatica). Shrub species include eastern red cedar, winged sumac and bush honeysuckle (Lonicera mackii). Japanese honeysuckle is also present. There is also Christmas fern present in the groundcover in some areas. Fragrant goldenrod (Solidago odora) is present on the fringes of the forest. 
Wetlands $\# 3$ and $\# 4$ are in a mowed turf grass area of the proposed haul road corridor (Fig. 7). These wetlands are approximately 0.01 and 0.33 acres in size, respectively. The two wetlands are split by the current road that runs through the area. Both wetlands have significant patches of black willow and cattail. Wetland \#3 also has rice cutgrass, small hop sedge, soft rush and umbrella sedge. Wetland \#4 is somewhat more diverse with rice cutgrass, blunt spikerush, small carpgrass, bushy seedbox (Ludwigia alternifolia), umbrella sedge (Cyperus flavescens), wool-grass (Scirpus cyperinus) and cardinal flower.

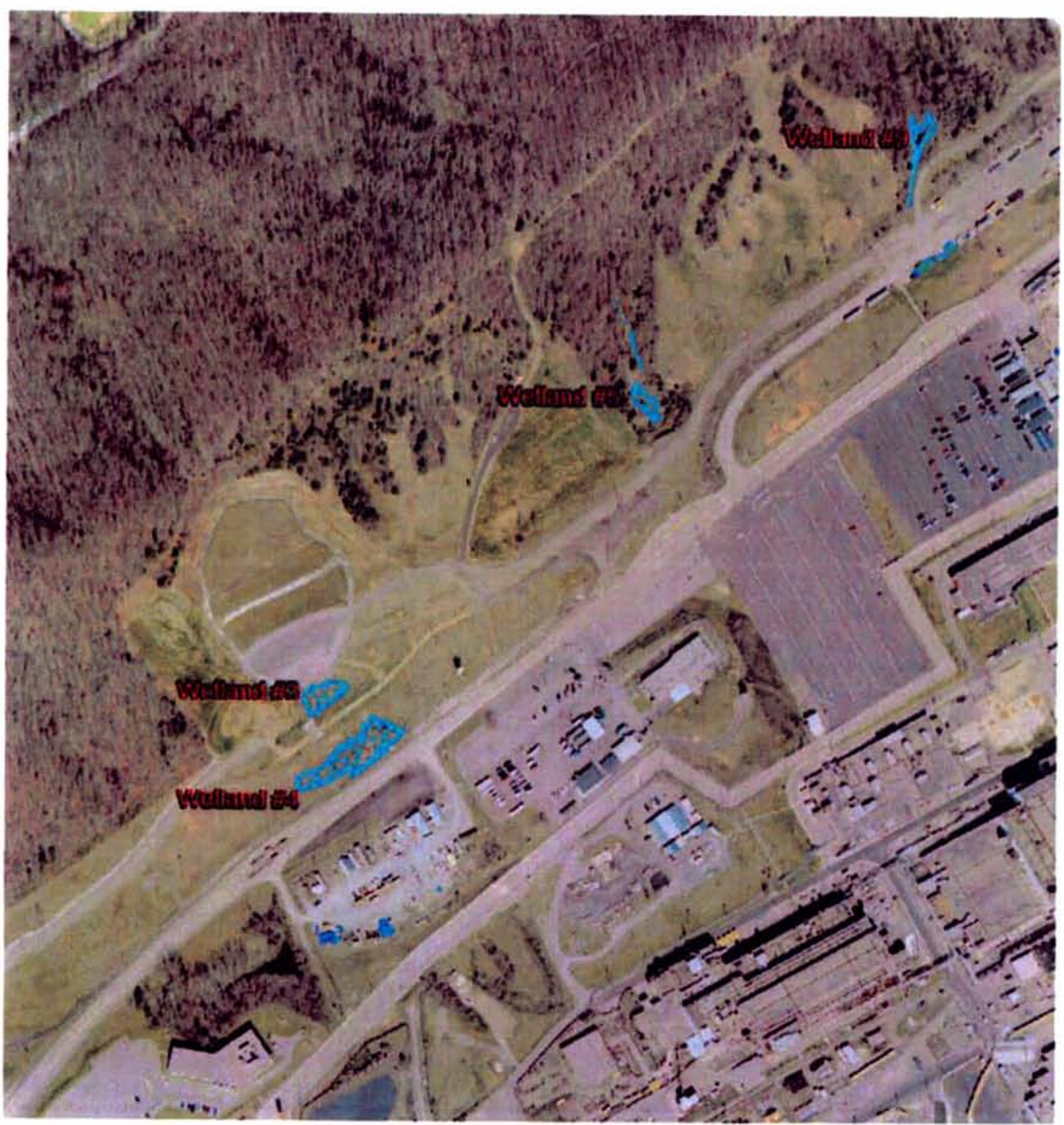

Fig. 7. Wetlands $\# 3, \# 4, \# 5$ and $\# 9$.

One of the wooded areas includes a wetland (Wetland \#5) (Fig. 7). This wetland is approximately 0.05 acres in size. This is a ravine that extends down from pine ridge. This ravine contains a spring that feeds an intermittent stream which flows down to Wetland \#5. Upland areas of the ravine contain mainly young second growth forest with a mixture of native and non-native trees and shrubs. Trees 
include sweetgum, tulip poplar and scrub pine (Pinus virginiana). Shrubs include autumn olive (Elaeagnus umbellata), thorny olive (Elaeagnus pungens), winged sumac and Japanese barberry (Berberis thunbergii). Blackberry and Japanese honeysuckle are also present. Lady fern is present in the groundcover. Herbaceous species include Nepal grass, crown vetch (Coronilla varia). Sericea lespedeza (Lespedeza cuneata) and Canada goldenrod (Solidago canadensis). Tree species in the wetland portion of the ravine include eastern cottonwood (Populus deltoides), red maple, black willow, American sycamore and common alder. Other plant species in the wetland include cattail, cardinal flower, soft rush. Scirpus sp., chufa (Cyperus exculentus), late-flowering thorough-wort (Eupatorium serotinum), willow-herb (Epilobium sp.), small carpgrass, bushy seedbox and dotted smartweed.

Wetland $\# 9$ is a previously flagged wetland just northwest of the Polaris Parking Lot (Fig. 7). This wetland is approximately 0.06 acres in size. The wetland has a shallow ponded area with limited wetland vegetation on the fringes. Wetland species include common alder, black willow and lateflowering thorough-wort. Additional plant species surrounding this wetland also include red maple, American beech. sweetgum, blackberry and lady fern. There is also a large patch of kudzu directly adjacent to the wetland on the east side. A drainage channel flows southward out of this wetland for a short distance along the existing road.

Table 1 shows acreages for all wetlands surveyed.

No rare plant species were found during the survey of this area.

Table 1. Wetland size and type for the UPF project

\begin{tabular}{|c|c|c|c|}
\hline Site & Acreage & Wetland type & $\begin{array}{c}\text { Description } \\
\end{array}$ \\
\hline$W \# 1$ & 0.30 & Forested wetland & $\begin{array}{l}\text { Narrow wooded wetland with pond adjacent to } \\
\text { power-line right-of-way }\end{array}$ \\
\hline $\mathrm{W} \# 2$ & 0.24 & Marsh & $\begin{array}{l}\text { Herbaceous vegetation with pond along power-line } \\
\text { right-of-way }\end{array}$ \\
\hline$W \# 3$ & 0.01 & Marsh & $\begin{array}{l}\text { Herbaceous and woody vegetation along power- } \\
\text { line right-of-way }\end{array}$ \\
\hline W \#4 & 0.33 & Marsh & $\begin{array}{l}\text { Herbaceous and woody vegetation along power- } \\
\text { line right-of-way }\end{array}$ \\
\hline$W \# 5$ & 0.05 & Forested wetland & $\begin{array}{l}\text { Narrow wooded wetland adjacent to power-line } \\
\text { right-of-way }\end{array}$ \\
\hline W \#6 & 0.06 & Marsh & $\begin{array}{l}\text { Herbaceous and woody vegetation along power- } \\
\text { line right-of-way }\end{array}$ \\
\hline$W \# 7$ & 0.32 & Forested wetland & $\begin{array}{l}\text { Herbaceous and forest vegetation along power-line } \\
\text { right-of-way }\end{array}$ \\
\hline W \#8 & 0.06 & Marsh & $\begin{array}{l}\text { Herbaceous and woody vegetation along power- } \\
\text { line right-of-way }\end{array}$ \\
\hline$W \# 9$ & 0.06 & Forested wetland & $\begin{array}{l}\text { Narrow wooded wetland with pond adjacent to } \\
\text { Polaris Parking Lot }\end{array}$ \\
\hline Total & 1.43 & & \\
\hline
\end{tabular}




\subsection{WET SOILS DISPOSAL AREA}

The Wet Soils Disposal Area is located at the former Control Burn Study Area on the north side of Bear Creek Road and bordered by the Environmental Management Waste Management Facility (EMWMF) Haul Road to the north. The site is mainly second growth woods with significant amounts of dead and down woody material. Figure 8 shows a portion of this area. There are blue line streams to the east and west of the site (Fig. 9). No wetlands were found within the area.

Bird Survey Results - A total of 13 bird species were identified in this habitat by either sight or song.

There were 5 species recorded at the site that are on the Partners In Flight (PIF) list as being of regional importance in the ridge and valley. One species in this category that frequents forested areas. the Carolina chickadee, was noted at the Wet Soils Disposal Area. The remaining PIF listed birds found on the site are those common to edge and old field habitats. A complete bird list for the Wet Soils Disposal Area is contained in Appendix C - Table C-4.

Small Mammal Survey Results - A total of 25 Sherman live traps were set out at the Wet Soils Disposal Area. Small mammals were trapped for a total of 5 nights. This is equal to a total of 125 trap nights ( 5 nights $\times 25$ traps).

White-footed mouse and golden mouse (Ochrotomys nuttalli) were the only species of small mammals captured in traps at the Wet Soils Disposal Area. White-tailed deer tracks were also noted on the site.

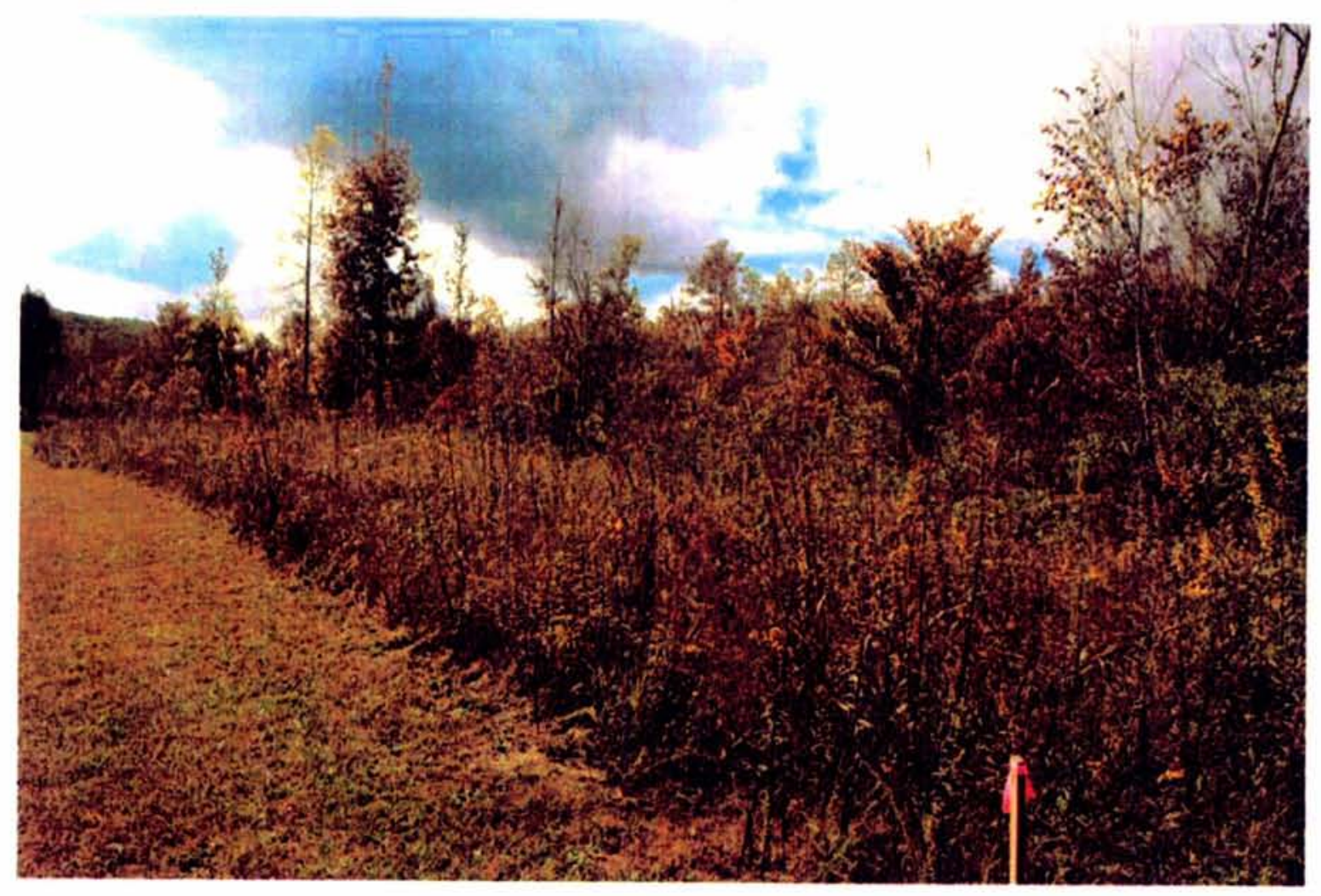

Fig. 8. Wet Soils Disposal Area. 


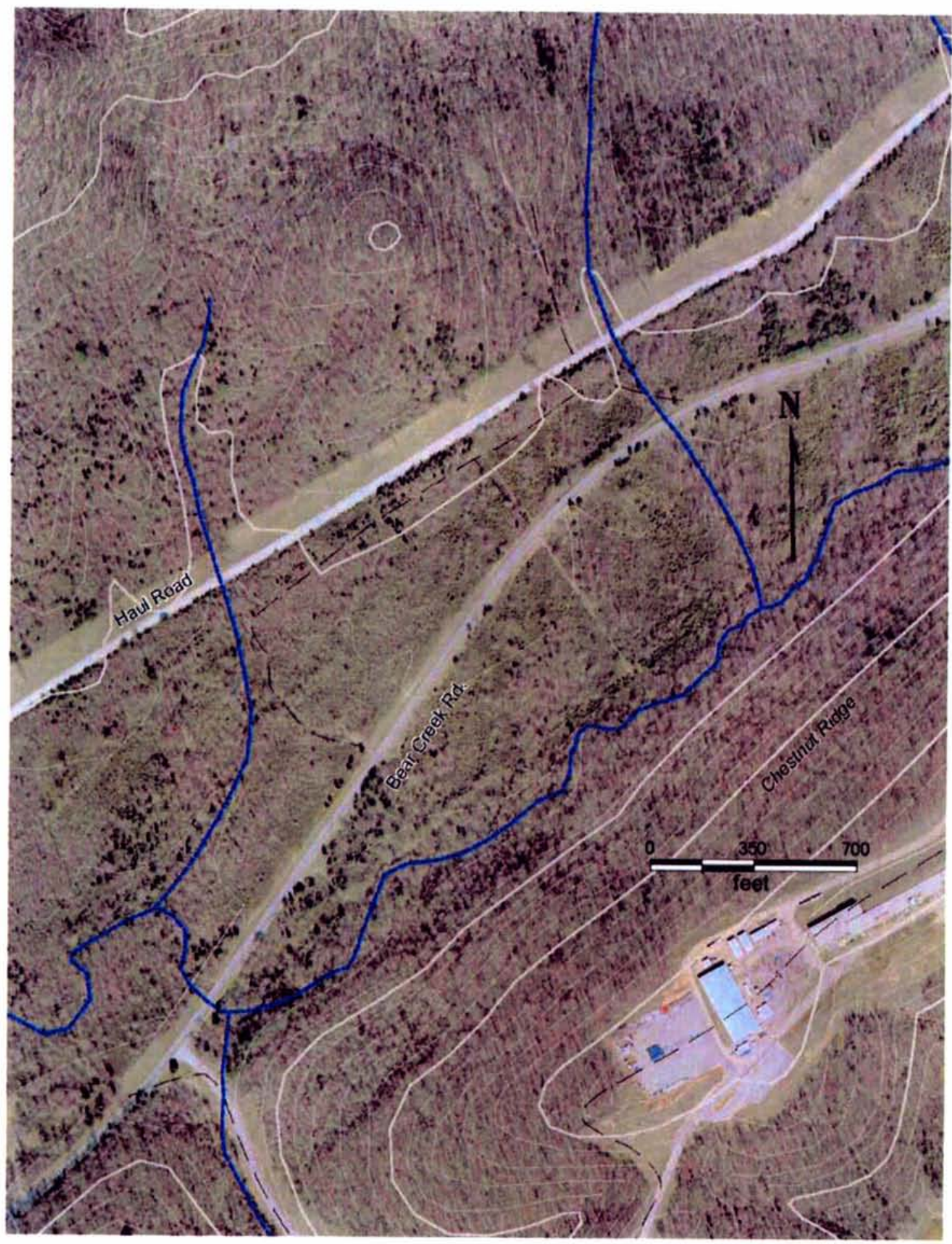

Fig. 9. Blue line streams in vicinity of Wet Soils Disposal Area.

Reptile and Amphibian Survey - A one day VES was conducted on the site. This involved searching under logs, rocks, bark, leaf litter and other debris. All reptiles and amphibians found were recorded. Incidental encounters with reptiles and amphibians were also recorded during surveys of other natural resources. 
The only species recorded on the site were black rat snake (Elaphe obsoleta obsoleta) and five-lined skink (Eumeces fasciatus).

Vegetation Survey - A one day walk-through was conducted at which time all vascular plant species that could be identified were recorded. An additional survey was conducted with a professional plant ecologist to specifically identify rare plants.

This is an area of second growth with mainly young trees. Vegetation is thick through most of the site and there is a significant amount of dead and down woody material. Young trees on the site include blackjack oak (Quercus marilandica), red maple, tulip poplar, loblolly pine (Pinus taeda), American sycamore, white oak and sweetgum. There is a diversity of shrub species on the site including bush honeysuckle, multiflora rose (Rosa multiflora). prairie rose (Rosa setigera), privet (Ligustrum sinense), smooth sumac and winged sumac. Blackberry is also prevalent on the site. Vines on the site include Japanese honeysuckle. Virginia creeper and poison ivy. There is a diversity of herbaceous species on the site including black-eyed susan (Rudbeckia hirta), Canada goldenrod, butterfly-weed (Asclepias tuberosa), joy-pye-weed (Eupatorium fistulosum), narrow-leaf sunflower and Queen-Anne's lace (Daucus carota). The southern perimeter of the site supports a variety of grass species including silver plume grass (Saccharum alopecuroides), little bluestem (Schizachyrium scoparium), big bluestem (Andropogon gerardii) and Indian grass (Sorghastrum nutans).

No rare plant species were recorded on this site. However, tubercled rein-orchid (Platanthera flava var. herbiola). a Tennessee threatened plant, is known from wetlands in the general area. Possible habitat for this species was noted in a wetland just west of the Wet Soils Disposal Area. Appendix C Table $\mathrm{C}-5$ has a complete list of plant species recorded on the site during the survey.

\subsection{WEST BORROW AREA}

The West Borrow Area, proposed for storage of dry soils, is an early successional field containing mainly herbaceous plant species. No wetlands were found within the area. Figure 10 shows a portion of this area.

Bird Survey Results - A total of 12 bird species were recorded on and adjacent to this site.

There were two bird species recorded at the site that are on the PIF list as being of regional importance in the ridge and valley. Species in this category that were noted on the site were the field sparrow (Spizella pusilla) and the indigo bunting (Passerina cyanea). Both of these species are common in edge and old field habitats. Appendix C - Table C -6 has a complete list of bird species recorded on and adjacent to this site.

Small Mammal Survey Results - A total of 25 Sherman live traps were set out at the West Borrow Area. Small mammals were trapped for a total of 5 nights. This is equal to a total of 125 trap nights ( 5 nights $\times 25$ traps). No small mammals were trapped on this site. Elk (Cervus canadensis) had been recorded in this area in the past.

Reptile and Amphibian Survey - A one day VES was conducted in this habitat. No reptile or amphibian species were noted in this habitat during the survey. However, green frogs (Rana clamitans melanota) and northern watersnakes (Nerodia sipedon sipedon) were recorded in the recharge basin to the south of the site. 


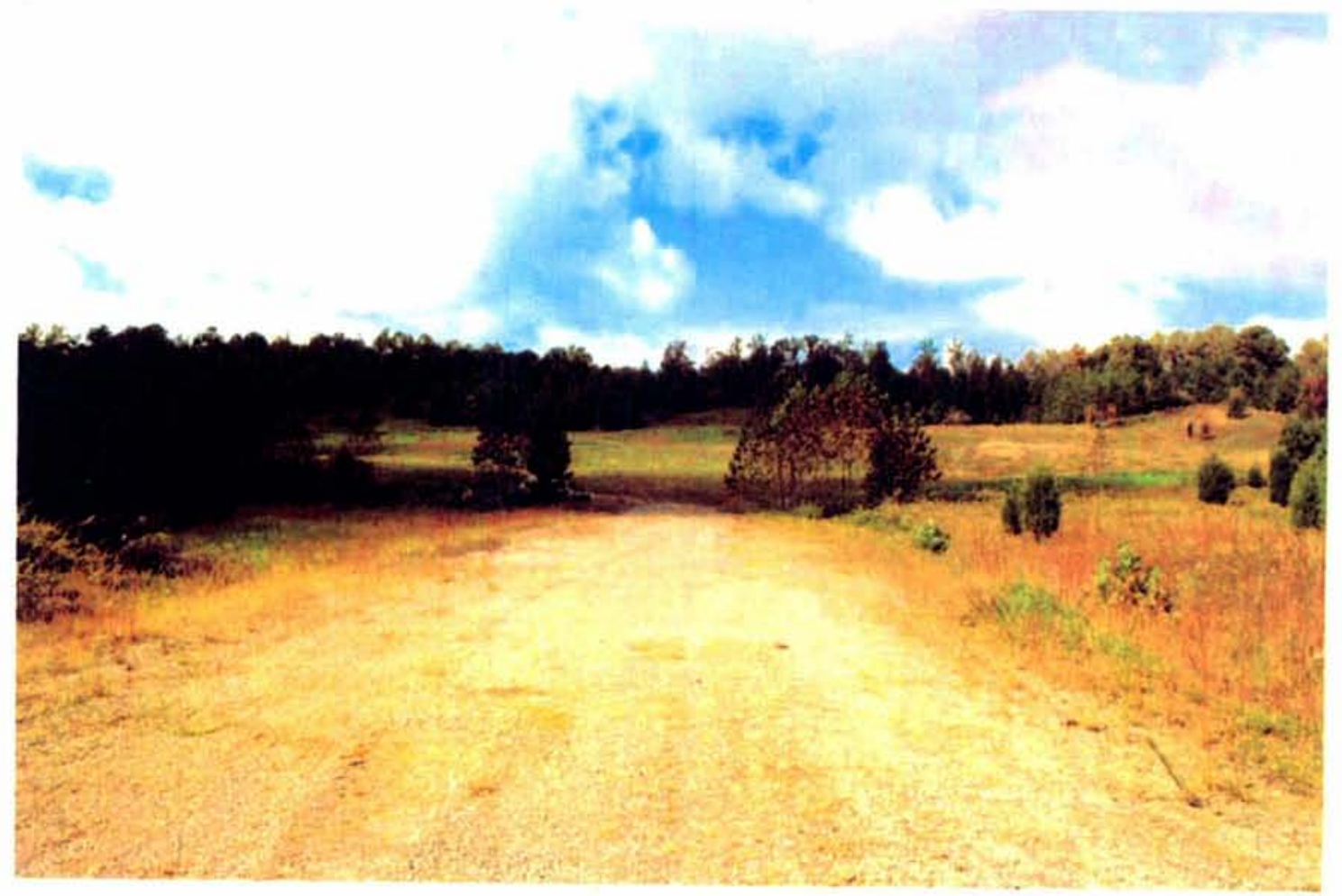

Fig. 10. West Borrow Area.

Vegetation Survey - - A one day walk-through was conducted at which time all vascular plant species that could be identified were recorded. An additional survey was conducted with a professional plant ecologist to specifically identify rare plants.

The site is an early successional field that contains mainly herbaceous plant species, with a few pockets of woody vegetation. The site contains a number of grass species including fescue, weeping lovegrass (Eragrostis curvula), little bluestem, barnyard grass (Echinocloa sp.), Johnson grass (Sorghum halepense) and poverty grass (Danthonia spicata). There is a relatively large area of little bluestem on the site. A number of goldenrod species are present on the site, along with a variety of other wildflower species.

Columnar prairie coneflower (Ratihada columnifera) was recorded at this site. This would be a significant occurrence if the plant had been found in its natural habitat, as it is a prairie species. Its occurrence here is clearly from planting or recent accidental introduction and thus not a significant occurrence. No other rare plant species were recorded on this site. A complete plant list for this site is contained in Appendix C - Table C-7.

\subsection{ADDITIONAL AREAS OF STUDY - POND NORTHEAST OF BUILDING 9114}

A pond just northeast of Building 9114 on the south side of Bear Creek Road was also studied during this survey. Minnow traps were placed in the pond to survey for amphibians. Red-spotted newts and green frogs were recorded in this pond. The main wetland plant in the pond is rice cutgrass. Smallspike false-nettle, late-flowering thorough-wort and dotted smartweed are also present. 
The pond is in a low area and is bordered by mature forest and edge habitat. The area slopes steeply from the pond into the upland forested area. The edges adjacent to a mowed grass area contain a variety of invasive plant species. It is isolated from other natural areas by roads and buildings.

Appendix C - Table C-8 contains a complete list of plant species found in this area. 
(THIS PAGE LEFT BLANK INTENTIONALLY) 


\section{DISCUSSION}

\subsection{WEST END HAUL ROAD CORRIDOR - NEW SALVAGE YARD TO WETLAND \#1}

This section of the haul road corridor includes old field, forest and wetland habitat. The most significant potential impacts will be due to disturbance to forest and wetland habitat.

Impacts to interior forest species due to habitat fragmentation and disturbance to potential bat roosting trees are the two major considerations with regard to forest impacts. The removal of potential bat roosting trees between April $1^{\text {st }}$ and October $14^{\text {th }}$ presents the potential for the disturbance of the federally endangered Indiana bat, a species whose known range includes the ORR. Trees providing potential bat roosting habitat (i.e., white oaks with exfoliating bark) were specifically noted on the western end of the proposed haul road corridor where it cuts north out of the power-line right-of-way into the forested area. Ten trees that fit this category were noted within the proposed haul road corridor in this area. An additional 15 trees (including one dead snag) were noted adjacent to the proposed haul road corridor in this area. All trees were marked with blue flagging for future reference. If potential bat roosting trees are to be removed during the April $1^{\text {st }}$ through October $14^{\text {th }}$ timeframe. mist netting must be conducted to determine presence or absence of the Indiana bat. U. S. Fish and Wildlife Service guidance allows for the removal of such trees between October $15^{\text {th }}$ and March $31^{\text {t }}$ when these tree roosting bats are absent.

The current route of the haul road will take it through or adjacent to five wetlands. The combined acreage of these wetlands is almost 1 acre. Direct disturbance and sedimentation into streams are two potential impacts. Disturbance to Wetlands $\# 1$ and $\# 2$, in particular, have the potential to impact significant amphibian populations.

\subsection{EAST END HAUL ROAD CORRIDOR - EAST OF WETLAND \#1 TO POLARIS PARKING LOT}

The eastern end of the haul road corridor extending from east of Wetland \#1 to the Polaris Parking Lot includes mowed areas, wetlands, limited early successional old field, and some forest. The greatest acreage in this area of the haul road corridor is in mowed turf grasses.

There is the potential for the disturbance and/or loss of wetland resources along this portion of the haul road. The current route of the haul road will take it through or adjacent to four wetlands. The combined acreage of these wetlands is almost $1 / 2$ acre.

\subsection{WET SOILS DISPOSAL AREA}

This site is mainly second growth woods with significant amounts of dead and down woody material. There are blue line streams to the east and west of the site.

The clearing of this site will result in the loss of habitat for common wildlife species found in second growth areas and edge habitat. An important consideration is the potential for disturbance to wet areas and streams to the east and west of the site, especially for the wetland to the west of the site where there is habitat present for the tubercled rein-orchid. 


\subsection{WEST BORROW AREA}

This site is mainly early successional old field.

The clearing of this site will result in loss of habitat for common field and edge wildlife species. 


\section{CONCLUSIONS}

In conclusion, the proposed haul road and soil storage areas for the UPF project traverse a variety of habitats including mowed areas, fields, second growth forest, mature forest and wetlands.

The fields and second growth areas are common and relatively non-sensitive habitats. As is evident from the results of surveys conducted, these areas support common wildlife species with stable populations and relatively wide distributions.

The mature forested areas along the proposed haul road provide habitat sensitive to encroachment. A major impact of encroachment on such forests is affects on interior forest bird species. The cumulative impact of road widening, construction and other projects through interior forests can result in significant overall impacts to bird populations. A number of interior forest bird species were recorded during the surveys conducted along the proposed UPF haul road corridor. A specific area of potential impact to forest bird species is along the western portion of the haul road where it travels northward through the forested area. An additional potential impact from disturbance of this habitat is the loss of potential bat roosting habitat that is provided by the exfoliating bark of mature white oaks and standing dead snags. The loss of such habitat has the potential to impact the federally endangered Indiana bat. Mature white oaks were recorded in the forest in this area.

The potential for impacts to wetland resources along the proposed haul road corridor is another major consideration prior to commencement of the project. This report documents the presence of jurisdictional wetlands within the current footprint of the proposed project. The final acreage of wetland impacts could change depending on final project location and/or design, and after consultation with appropriate regulatory authorities. Similarly, any mitigation requirements in conjunction with the wetland loss will depend on future project decisions and regulatory input. As currently proposed, the total wetland impact is greater than 0.1 acres and the wetlands have a hydrological connection to the streams in the watershed. Therefore, the wetlands are not isolated and a permit for minor wetland alterations cannot be used to satisfy State regulatory requirements. A TDEC ARAP Permit will be required and there is a strong likelihood that wetland mitigation, such as wetland creation, restoration, or enhancement, will be required. The Army Corps of Engineers will also need to be consulted and/or notified. It is recommended that a wetland mitigation plan be developed to address proposed steps to be taken to mitigate wetland disturbances and losses. This plan should be submitted as part of the ARAP Permit.

The current footprint of the haul road corridor crosses a number of wet weather conveyances or intermittent streams, but does not directly cross "jurisdictional" streams with established biological communities. However, streams defined as waters of the state (i.e., blue line streams with fish and snails, etc.) are found immediately downhill of some of the wetlands within the corridor. Proper erosion control and other BMPs will need to be implemented to avoid impacts to downstream aquatic resources, and changes to flow to downstream waters should be avoided. Bear Creek and its major tributaries contain a rare fish species, and forested wetlands adjacent to these streams are generally of high natural quality.

The fish communities in the Bear Creek Watershed have been monitored by the ORNL Biological Monitoring and Abatement Program (BMAP) since 1984. The biological communities in the Bear Creek Watershed have been impacted by prior waste disposal practices in its headwaters and current land uses (Southworth et.al. 1992; Hinzman 1996). However, Bear Creek and its tributaries are frequented by the Tennessee dace, a fish species that is listed by the State as "In Need of 
Management". and is afforded a level of protection that requires that its habitat be protected and not knowingly destroyed. This dace is found in the Ridge and Valley province of Tennessee with limited populations; the population in the Bear Creek Watershed has been indicated as one of the primary strongholds of the species in Tennessee (Etnier and Starnes 1993). The reproductive biology of the Tennessee dace represents the most critical aspect of its life cycle that could be impacted by projects in the Bear Creek Watershed. Several conditions are necessary for successful spawning of the Tennessee dace to occur. First, flow must be continuous throughout the spawning season (spring to early summer). Second, dace move into small streams during spawning and access for migration must be maintained throughout the watershed to allow for formation of aggregations. Thirdly, excess sedimentation to streams must be limited during the spawning season. Males of host species will continue to maintain a nest when sedimentation occurs, but if it is excessive, they will abandon the nests. Extended periods of sedimentation can result in a total spawning failure for the year. Because Tennessee dace are short-lived, consecutive poor spawning seasons could have a detrimental effect on the overall population viability in a watershed. Due to concerns for this fish species, extreme measures were taken during the construction of the Environmental Management Waste Management Facility (EMWMF) Haul Road. This included the implementation of unusual engineering designs in constructing the Haul Road bridge over Bear Creek, and unique culvert designs for Bear Creek tributary crossings (Peterson et. al. 2005).

Site-specific control measures of particular importance to protecting the Tennessee dace include using appropriately sized culverts and box bridges to prevent the impoundment of normal and base flows: using box bridges where appropriate to minimize impacts to existing streams with sensitive habitat: and designing specific oversized, partially submerged culverts with light infiltration to maintain and support fish movement. In addition to the design of crossings, the timing of construction to be outside the critical periods when migration and reproductive activities of the Tennessee dace are at a peak is of great importance. Several researchers have suggested that the spawning season spans the April to July timeframe in Tennessee (Starnes and Jenkins 1988; Etnier and Starnes 1993). Unpublished observations by E. M. Schilling and M. G. Ryon indicate that spawning occurs on the ORR from late March (after March 15) through the end of May. There is likely some variability in the spawning season depending on variations in flow, water temperature and host spawning activity, which could extend spawning through June if earlier conditions are unfavorable. Larval development proceeds for the two months following the spawn, with larval and juvenile fish occupying shallow, low water velocity areas adjacent to pools (Peterson et. al. 2005).

The contribution of the current project to cumulative impacts to the Bear Creek Watershed resulting from other projects should be taken into consideration. There are many environmental issues that could potentially impact the Bear Creek Watershed in the future.

Post construction control measures should be taken to prevent the spread of invasive species. Species such as kudzu, Nepal grass, autumn olive, lespedeza, and privet are just some of the invasive plants that can become established immediately after soil disturbance. Use of native plants in re-vegetating side slopes is one possibility for preventing the spread of invasive plants. Alternatively, not all areas can be seeded/re-vegetated. Application of straw (not hay) and use of silt fences could be adequate in many areas, and would allow native species to grow back to the road. Fire ants are a recent problem in construction zones and have been encountered in the project area. These ants may need to be controlled shortly after construction.

In summary, the following mitigation measures will aid in minimizing potential overall impacts to natural resources for the proposed UPF project: 
- Restriction of the impacted area to the maximum extent possible to mowed areas and fields Were common wildlife and habitats are present;

where, 3 lublio

- Minimizing encroachment into and fragmentation of mature forested areas in order to avoid major impacts to interior forest birds and potential bat roosting habitat;

- Minimizing disturbance to wetlands, especially those that contain significant amphibian populations;

- Minimizing impacts to streams and wet-weather conveyances, especially in the Bear Creek tributaries that provide habitat for the Tennessee dace. 
(THIS PAGE LEFT BLANK INTENTIONALLY) 


\section{REFERENCES}

ACOE (Army Corps of Engineers). 1987. Wetlands Delineation Manual. U. S. Army Corps of Engineers. Technical Report Y-87-1. Waterways Experiment Station, Vicksburg, MS.

Etnier, D. A. and W. C. Starnes. 1993. The Fishes of Tennessee. University of Tennessee Press, Knoxville, TN.

Harvey, M. J., J. S. Altenbach, and T. L. Best. 1999. Bats of the United States. Arkansas Fish \& Game Commission in cooperation with the Ashville Field Office, U. S. Fish and Wildlife Service, 64 pp.

Hinzman, R.L. (ed.). 1996. Report on the Biological Monitoring Program for Bear Creek at the Oak Ridge Y-12 Plant, Oak Ridge, Tennessee (1989-1994). ORNL/TM-12884. Oak Ridge National Laboratory, Oak Ridge, TN.

Jensen, J. B.. C. D. Camp, W. Gibbons, and M. J. Elliott. 2008. Amphibians and Reptiles of Georgia. The University of Georgia Press, Athens, Georgia. $575 \mathrm{pp}$.

Nicholson, C. P. 1997. Atlas of the Breeding Birds of Tennessee. The University of Tennessee Press, Knoxville, TN. 426 pp.

Peterson, M. J., N. R. Giffen, M. G. Ryon, L. R. Pounds, and E. L. Ryan Jr. 2005. Environmental Survey Report for the ETTP: Environmental Management Waste Management Facility (EMWMF) Haul Road Corridor, Oak Ridge, Tennessee. ORNL/TM-2005/215. Oak Ridge National Laboratory, Oak Ridge. TN.

Reid, F. A. 2006. Mammals of North America. The Peterson Field Guide Series, Houghton Mifflin Company, New York. 579 pp.

Southworth, G. R., J. M. Loar, M. G. Ryon, J. G. Smith, A. J. Stewart, and J. A. Burris. 1992. Ecological Effects of Contaminants and Remedial Actions in Bear Creek. ORNL/TM-11977. Oak Ridge National Laboratory, Oak Ridge, TN.

Starnes, W. C. and R. E. Jenkins. 1988. A new cyprinid fish of the genus Phoxinus (Pisces: Cypriniformes) from the Tennessee River drainage with comments on relationships and biogeography. Proc. Biol. Soc. Wash. 101(3): 517-529. 
(THIS PAGE LEFT BLANK INTENTIONALLY) 
Appendix A

CREDENTIALS AND QUALIFICATIONS 
(THIS PAGE LEFT BLANK INTENTIONALLY) 


\section{$\underline{\text { Neil Giffen }}$}

Education: Master of Science Degree in Wildlife Management, University of Maryland

Experience: Mr. Giffen has over 25 years experience in the fields of wildlife management and environmental sciences. He is experienced in a variety of wildlife survey techniques involving birds, mammals, and reptiles and amphibians. For the past 6 years Mr. Giffen has been the Wildlife Management Coordinator for the Oak Ridge Reservation. His current duties include overseeing, deer hunts, turkey hunts, Canada goose management, nuisance wildlife management and wildlife population inventories.

\section{Mark Peterson}

Mark Peterson has over 25 years of environmental assessment experience focused on the effects of Department of Energy and Defense missions on aquatic and wetland ecosystems. A certified Professional Wetland Scientist, he has conducted hundreds of wetland assessments, including determinations and delineations per ACOE protocols, EIS and EA evaluations of affected wetland environments, and natural quality evaluations using floral and faunal community and T\&E species data. Mr. Peterson's early career focused on natural quality assessment of Illinois floodplain ponds for his graduate work (Masters, Southern Illinois University, 1988) and The Nature Conservancy. He joined ORNL in 1988 where he has studied a wide variety of aquatic and wetland community types across the U.S. and Canada, including man-made and natural communities (e.g., vernal pools, glacial potholes, sphagnum bogs, longleaf pine ponds, swamp/rainforest, desert wash communities, and arctic wetland tundra). Recent interests include development of innovative pond and wetland restoration strategies. Mr. Peterson is currently the Science Team Leader for the Ecological Assessment Group at Oak Ridge National Laboratory, and the Program Manager for the Biological Monitoring and Abatement Program.

\section{$\underline{\text { Scott Reasor }}$}

Education: Bachelor of Science Degree in Wildlife and Fisheries Science and Management, Minor in Forestry, University of Tennessee

Experience: Mr. Reasor has one year of work experience in wildlife science and management with the Tennessee Wildlife Resources Agency and Oak Ridge National Laboratory (ORNL). He is currently an Oak Ridge Institute for Science and Education technician with the ORNL Environmental Sciences Division.

\section{Larry Pounds}

Education: Ph.D. in Ecology, University of Tennessee

Experience: Dr. Pounds has 22 years experience as a plant ecologist. He specializes in endangered plant species, special plant communities and exotic pest plants. Dr. Pounds is currently working as an endangered plant specialist for Oak Ridge National Laboratory and the Tennessee Valley Authority Heritage Project. His work at Oak Ridge National Laboratory includes the study of special plant communities, in particular, cedar barrens and wetlands. 


\section{Greg Bvrd}

Education: Bachelor of Science Degree in Forest Resources Management, University of Tennessee

Experience: Mr. Byrd has 20 years of work experience as the Oak Ridge Reservation forester. He is a member of the International Association of Wildland Fire (IAWF). Mr. Byrd is also skilled in the use of Global Positioning Systems (GPS) equipment, in particular, high accuracy Trimble units. 
Appendix B

\section{REPRESENTATIVE WETLAND DELINEATION REPORTS}


(THIS PAGE LEFT BLANK INTENTIONALLY) 
Table B-1. Wetland \#4

Project Site: UPF Project/Wetland $\# 4$

Applicant/Owner: Mick Wiest, Y-12 Staff

Investigator: M. J. Peterson (ORNL), N. R. Giffen (ORNL)

Do Normal Circumstances Exist on the site?: Yes

Is the site significantly disturbed (Atypical Situation): No

Is the area a potential Problem Area? No
Date: 21 September 2009

Location: Bear Creek Road, Y-12

National Security Complex, Anderson

County

State: TN

Commun. ID: Marsh

Monitoring Point: West end, Wetland

$\# 4$

\section{VEGETATION}

\begin{tabular}{|c|c|c|c|c|c|}
\hline Dominant Plant Species & Stratum & $\begin{array}{l}\text { Indi- } \\
\text { cator }\end{array}$ & Dominant Plant Species & Stratum & $\begin{array}{l}\text { Indi- } \\
\text { cator }\end{array}$ \\
\hline Salix nigra & tree & OBL & Scirpus cyperinus & herb & $\mathrm{OBL}$ \\
\hline Typhasp. & herb & OBL & Lohelia cardinalis & herb & $\mathrm{OBL}$ \\
\hline Leersia oryzoides & herb & OBL & & & \\
\hline Eleocharis obtuse & herb & OBL & & & \\
\hline Arthraxon hispidus & herb & FACW & & & \\
\hline Ludwigia alternafolia & herb & OBL & & & \\
\hline Cyperus flavescens & herb & OBL & & & \\
\hline
\end{tabular}

Percent of Dominant Species that are OBL, FACW or FAC (excluding FAC-): $100 \%$

Remarks: The dominant plants are wetland species. Fescue is dominant just outside the wetland zone,

especially around the seep areas.

\section{HYDROLOGY}

\begin{tabular}{|c|c|}
\hline X Recorded Data (Describe in Remarks): & Wetland hydrology Indicators: \\
\hline Stream, Lake, or Tide Gauge & Primary Indicators: \\
\hline Aerial Photographs & X Inundated \\
\hline Other & Water Marks \\
\hline No Recorded Data Available & D Drainage Patterns in Wetlands \\
\hline Field Observations: & D Sediment Deposits \\
\hline $\begin{array}{c}\text { Depth of Surface Water: At least 30\% surface } \\
\text { water, ranging from surface to 12 inches deep. }\end{array}$ & $\begin{array}{c}\text { Depth to Saturated Soil outside the ponded zone: } \\
\text { saturated at surface }\end{array}$ \\
\hline Depth of Water in Soil Pit: 4 inches & Secondary Indicators \\
\hline & Oxidized Root Channels in upper 12" \\
\hline & Water-Stained Leaves \\
\hline & Local Soil Survey Data \\
\hline & FAC-Neutral Test \\
\hline & Other (Explain in Remarks) \\
\hline
\end{tabular}

Remarks:

Some of the rust-colored seep inputs have been previously investigated and found to be natural (M. Wiest, personal communication). Similar tributary wetlands were identified west of the site by Rostensteel (1993). Small wetlands and ponding as a result of berms or road crossings are common features of Bear Creek's north tributaries. 


\begin{tabular}{|ll}
\hline Project/Site: UPF Project/Wetland $\# 4$ & Date: 21 September 2009 \\
Applicant/Owner: Mick Wiest, Y-12 Staff & Location: Bear Creek Road, Y-12 \\
& National Security Complex, Anderson \\
& County \\
Investigator: M. J. Peterson (ORNL), N. R. Giffen (ORNL) & State: TN \\
\hline
\end{tabular}

\section{SOILS}

Classification

Fine, silty to sandy loam, mixed, thermic, Typic Endoaqualf. Such hydric soils are characteristic of Pine Ridge terraces and shallow sloped tributary areas (4-6\% slope) of Bear Creek valley. Surrounding soils on the $12-20 \%$ slopes are Armuchee shaly, silty clay loam (Anderson County Soil Survey). Highly organic, fibrous root material in A horizon. All soils in this area of Pine Ridge underlain by multicolored shale, siltstone, and sandstone. Strong evidence of soil mixing in some areas, with little or no horizon development below the A horizon. Underlaying rock at surface or just below the A horizon, especially at steep banks where soils removed by historical earth moving activities. Areas with surface water have shallow organic horizon on top of loose rock (either bedrock or old fill). Soils vary by location. Extensive erosion and depositing of upland soils in the area.

Profile Description:

\begin{tabular}{|l|l|l|l|l|l|}
\hline $\begin{array}{l}\text { Depth } \\
\text { (in.) }\end{array}$ & Horizon & \multicolumn{1}{|c|}{$\begin{array}{c}\text { Matrix } \\
\text { Color }\end{array}$} & $\begin{array}{c}\text { Mottle } \\
\text { Colors }\end{array}$ & \multicolumn{1}{|c|}{$\begin{array}{c}\text { Mottle } \\
\text { Abundance/Contrast }\end{array}$} & $\begin{array}{c}\text { Texture. Concretions, } \\
\text { Structures }\end{array}$ \\
\hline $0-2^{\prime \prime}$ & A & 10YR 5/1 & none & none & Fibric \\
\hline $2-12^{*}$ & B & $\begin{array}{l}\text { Mixed; } \\
7.5 \text { YR 6/1, } \\
7.5 \text { YR 7/6 }\end{array}$ & 10R 4/4 & $20 \%$ of matrix & \\
\hline
\end{tabular}

\begin{tabular}{|l}
\hline Hydric Soil Indicators: \\
Histosol \\
Histic Epipedon \\
Sulfidic Odor \\
X_Aquic Moisture Regime \\
X_ Reducing Conditions \\
X_ Gleyed or Low-Chroma Colors
\end{tabular}

Concretions

High Organic Content in Surface Layer Sandy Soils

Organic Streaking in Sandy Soils

$X$ Listed on State Hydric Soils List Listed on National Hydric Soils List Other (Explain in Remarks)

Remarks: Soils show strong evidence of sustained wet conditions toward center of site. Soils near periphery of wet zone shallow, not well developed, or absent. Water in soil near surface of these peripheral sites due to surface flow from seeps, little or no saturation in small B horizon. Soil mixing, high shale deposits, shallow soil. and layering of eroded upland soils are all clear evidence of previous soil disturbances in this area.

\section{WETLAND DETERMINATION}

Hydrophytic Vegetation Present? YES

Wetland Hydrology Present? YES

Hydric Soils Present? Is this sampling point within a wetland? YES

Remarks: This site has the necessary vegetation, soils, and hydrology to be classified a jurisdictional wetland. Native wetland species are dominant, particularly in the area of standing water, but the site shows strong evidence of human disturbance, particularly along the edges and where seeps enter the site. Evidence of previous earth moving activities that removed or mixed soil. Periphery of site regularly mowed. 
Table B-2. Wetland $\# 7$

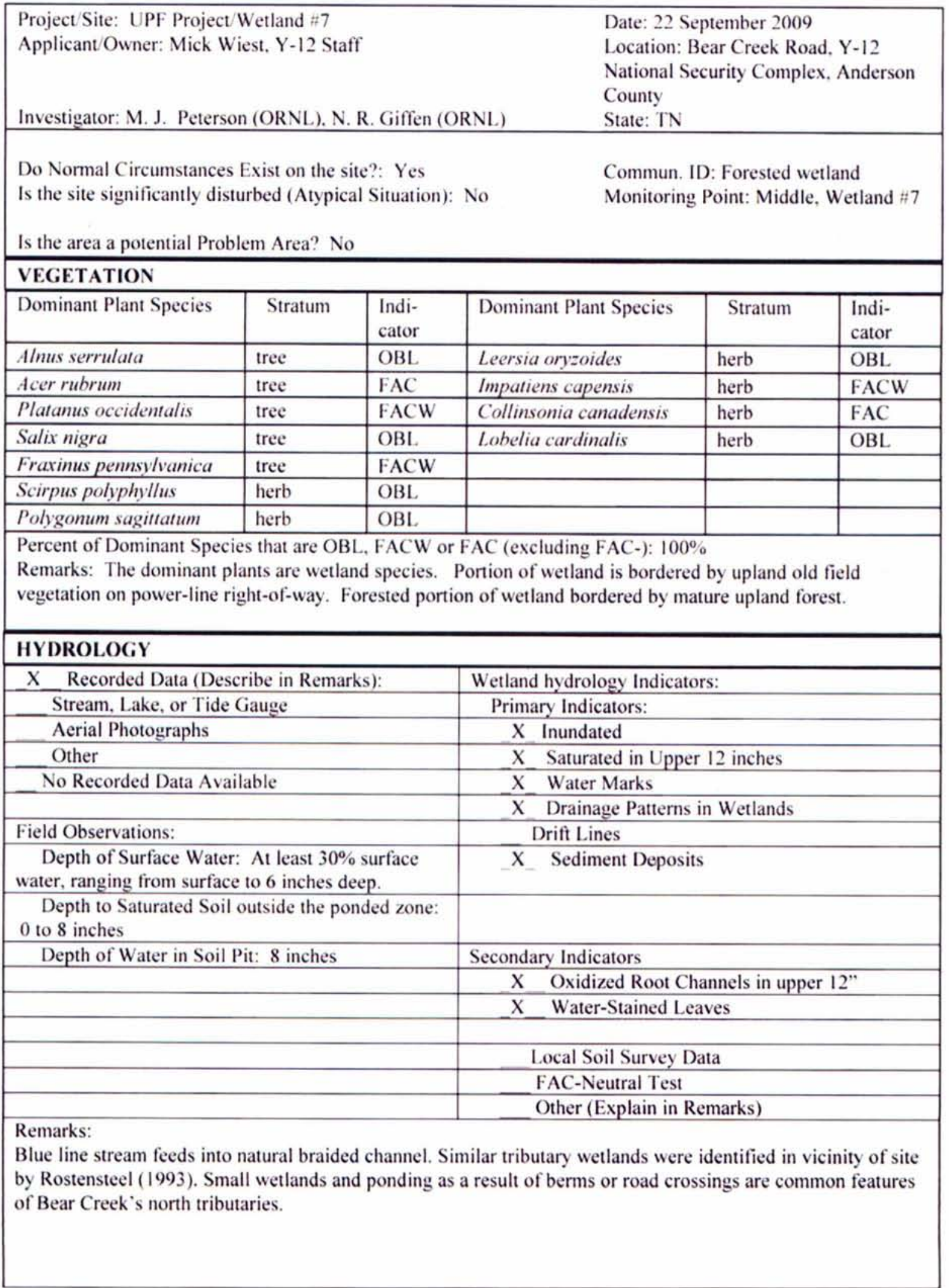




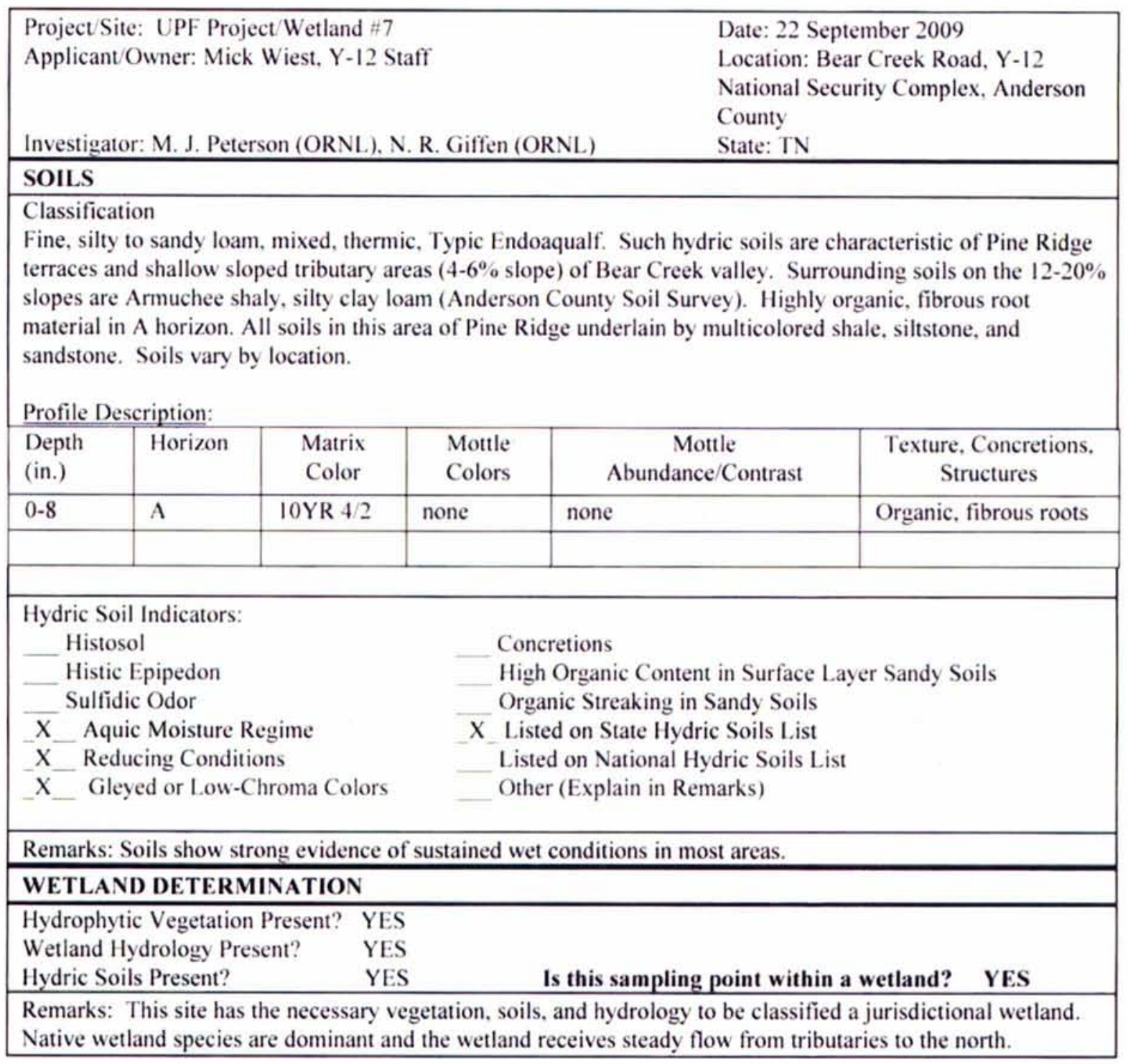


Appendix $\mathbf{C}$

FAUNA AND FLORA LISTS 
(THIS PAGE LEFT BLANK INTENTIONALLY) 
Table C-1. Bird species list - haul road corridor

\begin{tabular}{|c|c|c|c|c|}
\hline \multirow{2}{*}{ Scientific name } & \multirow{2}{*}{ Common name } & \multirow{2}{*}{ Habitat } & \multicolumn{2}{|l|}{ Status } \\
\hline & & & Federal & PIF $^{c}$ \\
\hline \multicolumn{5}{|l|}{ VULTURES } \\
\hline Cathartes aura & turkey vulture & flyover & & \\
\hline \multicolumn{5}{|l|}{ CUCKOOS } \\
\hline Coccyzus americamus & yellow-billed cuckoo & forest & & \\
\hline \multicolumn{5}{|l|}{ OWLS } \\
\hline Otus asio & eastern screech-owl & forest & & \\
\hline \multicolumn{5}{|l|}{ KINGFISHERS } \\
\hline Ceryle alcyon & belted kingfisher & wetland & & RI \\
\hline \multicolumn{5}{|l|}{ WOODPECKERS } \\
\hline Melanerpes carolimus & red-bellied woodpecker & forest & & \\
\hline Picoides villosus & hairy woodpecker & forest & & \\
\hline Picoides pubescens & downy woodpecker & forest & & RI \\
\hline Dryocopus pileatus & pileated woodpecker & forest & & \\
\hline \multicolumn{5}{|l|}{ TYRANT FLYCATCHERS } \\
\hline Sayornis phoebe & eastern phoebe & edge & & \\
\hline Contopus virens & eastern wood-pewee & forest & & $\mathrm{RI}$ \\
\hline \multicolumn{5}{|l|}{ VIREOS } \\
\hline Vireo griseus & white-eyed vireo & edge & & \\
\hline \multicolumn{5}{|l|}{ CROWS AND.JAYS } \\
\hline Cyanocitta cristata & blue jay & forest & & \\
\hline Corvus brachyrhynchos & American crow & forest & & \\
\hline \multicolumn{5}{|c|}{ CHICKADEES AND TITMICE } \\
\hline Baeolophus bicolor & tufted titmouse & forest & & \\
\hline Poecile carolinensis & Carolina chickadee & forest & & RI \\
\hline \multicolumn{5}{|l|}{ NUTHATCHES } \\
\hline Sitta carolinensis & white-breasted nuthatch & forest & & \\
\hline \multicolumn{5}{|l|}{ WRENS } \\
\hline Thryothorus /udoviciamus & Carolina wren & edge & & \\
\hline \multicolumn{5}{|l|}{ THRUSHES } \\
\hline Sialia sialis & eastern bluebird & edge & & \\
\hline \multicolumn{5}{|c|}{ MOCKINGBIRDS AND THRASHERS } \\
\hline Dumetella carolinensis & gray catbird & edge & & \\
\hline \multicolumn{5}{|l|}{ WOOD-WARBLERS } \\
\hline Geothlypis trichas & common yellowthroat & edge & & \\
\hline \multicolumn{5}{|l|}{ TOWHEES } \\
\hline Pipilo erythrophthalmus & eastern towhee & edge & & RI \\
\hline BUNTINGS & & & & \\
\hline
\end{tabular}




\begin{tabular}{|llllc|}
\hline \multirow{2}{*}{ Scientific name } & Common name & Habitat & & Status \\
\cline { 3 - 5 } & & Federal & State & PIF $^{c}$ \\
\hline Passerina cyanea & indigo bunting & edge & & RI \\
\hline FINCHES & & & & \\
\hline Carduelis tristis & American goldfinch & edge & & \\
\hline
\end{tabular}

RI = regional importance

'Partners In Flight 
Table C-2. Reptile and amphibian species list - haul road corridor

\begin{tabular}{|c|c|c|c|c|}
\hline \multirow{2}{*}{ Scientific name } & \multirow{2}{*}{ Common name } & \multirow{2}{*}{ Location } & \multicolumn{2}{|c|}{ Status } \\
\hline & & & Federal & State \\
\hline \multicolumn{5}{|c|}{ AMPHIBIANS - ORDER CAUDATA } \\
\hline Ambystoma opacum & marbled salamander & Wetland $\# 2$ & & \\
\hline $\begin{array}{l}\text { Notophthalmus viridescens } \\
\text { viridescens }\end{array}$ & red-spotted newt & $\begin{array}{l}\text { Forest and } \\
\text { Wetlands } \# 1 \text { and } \# 2\end{array}$ & & \\
\hline Desmognathus sp. & dusky salamander & streams & & \\
\hline \multicolumn{5}{|c|}{ AMPHIBIANS - ORDER ANURA } \\
\hline Pseudacris crucifer crucifer & northern spring peeper & Wetland $\# 7$ & & \\
\hline Pseudacris feriarum feriarum & upland chorus frog & Wetland $\# 4$ & & \\
\hline Rana catesbeiana & American bullfrog & Wetland $\# 1$ & & \\
\hline Rana clamitans melanota & green frog & Wetland \#1 & & \\
\hline Rana palustris & Pickerel frog & $\begin{array}{l}\text { western power-line } \\
\text { area, Wetland } \# 1\end{array}$ & & \\
\hline Schaphiopus holbrookii & eastern spadefoot & Wetland $\# 6$ & & \\
\hline \multicolumn{5}{|c|}{ REPTILES - ORDER TESTUDINES } \\
\hline Terrepene carolina carolina & eastern box turtle & Wetland $\# 7$ & & \\
\hline \multicolumn{5}{|c|}{ REPTILES - ORDER TESTUDINES - SUBORDER IGUANIA } \\
\hline $\begin{array}{l}\text { Sceloporus undulatus } \\
\text { hyacinthimus }\end{array}$ & northern fence lizard & $\begin{array}{l}\text { western power-line } \\
\text { area }\end{array}$ & & \\
\hline
\end{tabular}


Table C-3. Plant species list for the haul road corridor

\begin{tabular}{|c|c|}
\hline Scientific name & Common name \\
\hline \multicolumn{2}{|l|}{ FOREST } \\
\hline Quercus alba & White oak \\
\hline Quercus montana & Chestnut oak \\
\hline Quercus falcata & Southern red oak \\
\hline Pinus virginiana & Scrub pine \\
\hline Pinus taeda & Loblolly pine \\
\hline Acer rubrum & Red maple \\
\hline Acer saccharum & Sugar maple \\
\hline Iuniperus virginiana & Eastern red cedar \\
\hline Liquidambar styraciflua & Sweetgum \\
\hline Liriodendron tulipifera & Tulip poplar \\
\hline Carya glabra & Pignut hickory \\
\hline Nyssa sy/vatica & Black gum \\
\hline Prumus serotina & Black cherry \\
\hline Fagus grandifolia & American beech \\
\hline Fraximus pennsy/vanica & Green ash \\
\hline Oxydendrum arboreum & Sourwood \\
\hline Cornus florida & Flowering dogwood \\
\hline Asimina triloba & Common pawpaw \\
\hline Vitis rotundifolia & Muscadine \\
\hline Elaeagnus umbellata & Autumn olive \\
\hline Elaeagnus pungens & Thorny olive \\
\hline Rhus copallina & Winged sumac \\
\hline Rhus radicans & Poison ivy \\
\hline Lonicera mackii & Bush honeysuckle \\
\hline Lonicera japonica & Japanese honeysuckle \\
\hline Vaccinium pallidum & Lowbush blueberry \\
\hline Rubus sp. & Blackberry \\
\hline Berberis thunbergii & Japanese barberry \\
\hline Parthenocissus quinquefolia & Virginia creeper \\
\hline Polystichum acrostichoides & Christmas fern \\
\hline Chimaphila maculata & Striped pipissewa \\
\hline Athyrium filix-femina & Lady fern \\
\hline Solidago canadensis & Canada goldenrod \\
\hline Solidago odora & fragrant goldenrod \\
\hline Lespedeza cuneata & Sericea lespedeza \\
\hline Microstegium vimineum & Nepal grass \\
\hline Coronilla varia & Crown vetch \\
\hline
\end{tabular}




\begin{tabular}{|c|c|}
\hline Scientific name & Common name \\
\hline Hexastylis arifolia & Little brown jug \\
\hline Perilla frutescens & Beefsteak plant \\
\hline Goodyera pubescens & Downy rattlesnake plantain \\
\hline \multicolumn{2}{|l|}{ WETL.ANDS } \\
\hline Salix nigra & Black willow \\
\hline Populus deltoides & Eastern cottonwood \\
\hline Acer rubrum & Red maple \\
\hline Fraxinus pennsy/vanica & Green ash \\
\hline Platanus occidentalis & American sycamore \\
\hline Alnus serrulata & Common alder \\
\hline Typhasp. & Cattail \\
\hline Sagittaria australis & Long-beaked arrow-head \\
\hline Lobelia puberula & Downy lobelia \\
\hline Lobelia cardinalis & Cardinal flower \\
\hline Helianthus angustifolius & Narrow-leaved sunflower \\
\hline Impatiens capensis & Orange jewelweed \\
\hline Arisaema triphyllum & Jack-in-the-pulpit \\
\hline Collinsonia canadensis & Horse-balm \\
\hline Mimulus ringens & Alleghany monkey-flower \\
\hline Polygonum sagittatum & Tearthumb \\
\hline Polygonum punctatum & Dotted smartweed \\
\hline Eupatorium serotimum & Late-flowering thorough-wort \\
\hline Epilobium sp. & Willow-herb \\
\hline Ludwigia alternifolia & Bushy seedbox \\
\hline Spiranthes sp. & Lady's tresses \\
\hline Fimbristylis autumnalis & Slender fimbry \\
\hline Boehmeria cylindrica & Small-spike false-nettle \\
\hline Arthraxon hispidus & Small carpgrass \\
\hline Leersia oryzoides & Rice cutgrass \\
\hline Carex lurida & Smaller hop sedge \\
\hline Cyperus flavescens & Umbrella sedge \\
\hline Cyperus strigosus & Umbrella sedge \\
\hline Cyperus esculentus & Chufa \\
\hline Eleocharis obtusa & Blunt spike-rush \\
\hline Juncus effusus & Soft rush \\
\hline Rhyncospora sp. & Beak-rush \\
\hline Scirpus polyphyllus & Leafy bulrush \\
\hline Scirpus cyperimus & Wool-grass \\
\hline OLD FIELD & \\
\hline
\end{tabular}




\begin{tabular}{|ll|}
\hline \multicolumn{1}{|c|}{ Scientific name } & Common name \\
\hline Salix nigra & Black willow \\
\hline Liquidambar styraciflua & Sweetgum \\
\hline Liriodendron tulipifera & Tulip poplar \\
\hline Rhus glabra & Smooth sumac \\
\hline Rhus copallina & Winged sumac \\
\hline Lonicera japonica & Japanese honeysuckle \\
\hline Rubus sp. & Blackberry \\
\hline Pueraria lobata & Kudzu \\
\hline Solidago canadensis & Canada goldenrod \\
\hline Solidago speciosa & Showy goldenrod \\
\hline Helianthus angustifolius & Narrow-leaved sunflower \\
\hline Vernonia gigantean & Tall ironweed \\
\hline Verhesina occidentalis & Crown-beard \\
\hline Ambrosia sp. & Ragweed \\
\hline Agalinis sp. & Gerardia \\
\hline Lobelia sp. & Lobelia \\
\hline Lespedeza cuneata & Sericea lespedeza \\
\hline Lespedeza repens & Trailing bush-clover \\
\hline Microstegium vimineum & Nepal grass \\
\hline Andropogon gerardii & Big bluestem \\
\hline Setaria sp. & Foxtail \\
\hline Panicum anceps & Panic grass \\
\hline Sorghum halepense & Johnson grass \\
\hline Festuca sp. & \\
\hline
\end{tabular}


Table C-4. Bird species list - Wet Soils Disposal Area

\begin{tabular}{|c|c|c|c|c|}
\hline \multirow{2}{*}{ Scientific name } & \multirow{2}{*}{ Common name } & \multirow[b]{2}{*}{ Habitat } & \multicolumn{2}{|l|}{ Status } \\
\hline & & & Federal & PIF $^{c}$ \\
\hline \multicolumn{5}{|l|}{ WOODCOCKS } \\
\hline Scolopax minor & American woodcock & $\begin{array}{l}\text { Second } \\
\text { growth }\end{array}$ & & \\
\hline \multicolumn{5}{|l|}{ WOODPECKERS } \\
\hline Melanerpes carolinus & red-bellied woodpecker & $\begin{array}{l}\text { Second } \\
\text { growth }\end{array}$ & & \\
\hline \multicolumn{5}{|l|}{ TYRANT FLYCATCHERS } \\
\hline Sayornis phoebe & eastern phoebe & Edge & & \\
\hline \multicolumn{5}{|l|}{ VIREOS } \\
\hline Vireo griseus & white-eyed vireo & edge & & \\
\hline \multicolumn{5}{|l|}{ CROWS AND.JAYS } \\
\hline Cyanocitta cristata & blue jay & $\begin{array}{l}\text { Second } \\
\text { growth }\end{array}$ & & \\
\hline Corvus brachyrhynchos & American crow & $\begin{array}{l}\text { Second } \\
\text { growth }\end{array}$ & & \\
\hline \multicolumn{5}{|c|}{ CHICKADEES AND TITMICE } \\
\hline Poecile carolinensis & Carolina chickadee & $\begin{array}{l}\text { Second } \\
\text { growth }\end{array}$ & & RI \\
\hline \multicolumn{5}{|l|}{ WRENS } \\
\hline Thryothorus ludovicianus & Carolina wren & edge & & \\
\hline \multicolumn{5}{|c|}{ MOCKINGBIRDS AND THRASHERS } \\
\hline Toxostoma rufum & Brown thrasher & edge & & RI \\
\hline \multicolumn{5}{|l|}{ WOOD-WARBLERS } \\
\hline Icteria virens & Yellow-breasted chat & edge & & RI \\
\hline \multicolumn{5}{|l|}{ TOWHEES } \\
\hline Pipilo erythrophthalmus & eastern towhee & edge & & RI \\
\hline \multicolumn{5}{|l|}{ BUNTINGS } \\
\hline Passerina cyanea & indigo bunting & edge & & RI \\
\hline \multicolumn{5}{|l|}{ FINCHES } \\
\hline Carduelis tristis & American goldfinch & edge & & \\
\hline
\end{tabular}

$\mathrm{RI}=$ regional importance

'Partners In Flight 
Table C-5. Plant species list for the Wet Soils Disposal Area

\begin{tabular}{|c|c|}
\hline Scientific name & Common name \\
\hline Quercus marilandica & Blackjack oak \\
\hline Acer rubrum & Red maple \\
\hline Liriodendron tulipifera & Tulip poplar \\
\hline Pinus taeda & Loblolly pine \\
\hline Platanus occidentalis & American sycamore \\
\hline Rhamnus caroliniana & Carolina buckthorn \\
\hline Fraximus pennsy/vanica & Green ash \\
\hline Fagus grandifolia & American beech \\
\hline Quercus alba & White oak \\
\hline Cormus florida & Flowering dogwood \\
\hline Juniperus virginiana & Eastern red cedar \\
\hline Cercis canadensis & Red bud \\
\hline Liquidambar styraciflua & Sweetgum \\
\hline Rhamnus caroliniana & Carolina buckthorn \\
\hline Corylus americana & American hazelnut \\
\hline Lonicera japonica & Japanese honeysuckle \\
\hline Lonicera maackii & Bush honeysuckle \\
\hline Rosa multiflora & Multiflora rose \\
\hline Rosa setigera & Prairie rose \\
\hline Ligustrum sinense & Privet \\
\hline Rhus glabra & Smooth sumac \\
\hline Rhus copallina & Winged sumac \\
\hline Rubus sp. & Blackberry \\
\hline Vitis rotundifolia & Muscadine \\
\hline Vaccinium pallidum & Pale lowbush blueberry \\
\hline Euonymus americamus & Heart's-a-bursting \\
\hline Parthenocissus quinquefolia & Virginia creeper \\
\hline Toxicodendron radicans & Poison ivy \\
\hline Wisteria sp. & Wisteria \\
\hline Botrychium dissectum & Common grape fern \\
\hline Polystichum acrostichoides & Christmas fern \\
\hline Heterotheca mariana & Shaggy golden aster \\
\hline Rudbeckia hirla & Black-eyed susan \\
\hline Lespedeza cuneata & Sericea lespedeza \\
\hline Silphium terebinthinaceum & Prairie dock \\
\hline Helianthus microcephalus & Small wood sunflower \\
\hline Panicum anceps & Panic grass \\
\hline Solidago canadensis & Canada goldenrod \\
\hline
\end{tabular}




\begin{tabular}{|ll|}
\hline \multicolumn{1}{|c|}{ Scientific name } & \multicolumn{1}{c|}{ Common name } \\
\hline Solidago speciosa & Showy goldenrod \\
\hline Solidago gigantea & Tall goldenrod \\
\hline Asclepias tuberosa & Butterfly-weed \\
\hline Eupatorium fistulosum & Joe-Pye-weed \\
\hline Saccharum alopecuroides & Silver plume grass \\
\hline Schizachyrium scoparium & Little bluestem \\
\hline Andropogon gerardii & Big bluestem \\
\hline Arthraxon hispidus & Small carpgrass \\
\hline Microstegium vimineum & Nepal grass \\
\hline Agrimonia sp & Agrimony \\
\hline Boehmeria cylindrica & Small-spike false-nettle \\
\hline Juncus effusus & Soft rush \\
\hline Aster dumosus & Bushy aster \\
\hline Anemone virginiana & Thimbleweed \\
\hline Sorghastrum nutans & Indian grass \\
\hline Asclepias sp. & milkweed \\
\hline Coreopsis tripteris & Tall tickseed \\
\hline Helianthamum autumnal & Sneezeweed \\
\hline Helianthus angustifolius & Narrow-leaved sunflower \\
\hline Daucus carota & Queen-Anne's lace \\
\hline
\end{tabular}


Table C-6. Bird species list - West Borrow Area

\begin{tabular}{|c|c|c|c|c|c|}
\hline \multirow{2}{*}{ Scientific name } & \multirow{2}{*}{ Common name } & \multirow{2}{*}{ Habitat } & \multicolumn{3}{|c|}{ Status } \\
\hline & & & Federal & State & PIF $^{c}$ \\
\hline \multicolumn{6}{|l|}{ TURKEYS } \\
\hline Meleagris gallopavo & Wild turkey & field & & & \\
\hline \multicolumn{6}{|l|}{ WOODPECKERS } \\
\hline Melanerpes carolinus & red-bellied woodpecker & forest & & & \\
\hline Dryocopus pileatus & Pileated woodpecker & forest & & & \\
\hline \multicolumn{6}{|l|}{ TYRANT FLYCATCHERS } \\
\hline Sayornis phoebe & eastern phoebe & edge & & & \\
\hline \multicolumn{6}{|l|}{ CROWS AND.JAYS } \\
\hline Cyanocitta cristata & blue jay & forest & & & \\
\hline Corvus brachyrhynchos & American crow & forest & & & \\
\hline \multicolumn{6}{|c|}{ CHICKADEES AND TITMICE } \\
\hline Baeolophus bicolor & tufted titmouse & forest & & & \\
\hline \multicolumn{6}{|l|}{ WRENS } \\
\hline Thryothorus ludovicianus & Carolina wren & edge & & & \\
\hline \multicolumn{6}{|l|}{ SPARROWS } \\
\hline Spizella pusilla & Field sparrow & field & & & RI \\
\hline \multicolumn{6}{|l|}{ CARDINALS } \\
\hline Cardinalis cardinalis & Northern cardinal & edge & & & \\
\hline \multicolumn{6}{|l|}{ BUNTINGS } \\
\hline Passerina cyanea & indigo bunting & edge & & & RI \\
\hline \multicolumn{6}{|l|}{ FINCHES } \\
\hline Carduelis tristis & American goldfinch & field & & & \\
\hline
\end{tabular}

$\mathrm{RI}=$ regional importance

'Partners In Flight 
Table C-7. Plant species list for West Borrow Area

\begin{tabular}{|c|c|}
\hline Scientific name & Common name \\
\hline Lespedeza cuneata & Sericea lespedeza \\
\hline Coronilla varia & Crown vetch \\
\hline Solidago canadensis & Canada goldenrod \\
\hline Echinocloa sp. & Barnyard grass \\
\hline Cyperus strigosus & Umbrella sedge \\
\hline Aster pilosus & Downy aster \\
\hline Iva annua & Rough marsh elder \\
\hline Ambrosia artemmisiufolia & ragweed \\
\hline Festuca sp. & fescue \\
\hline Juncus effusus & Soft rush \\
\hline Eleocharis obtusa & Spike rush \\
\hline Eragrostis curvula & Weeping lovegrass \\
\hline Schizachyrium scoparium & Little bluestem \\
\hline Solidago speciosa & Showy goldenrod \\
\hline Aster dumosus & Bushy aster \\
\hline Ageratina aromatica & Lesser snakeroot \\
\hline Helianthus angustifolius & Narrow-leaved sunflower \\
\hline Perilla frutescens & beefsteakplant \\
\hline Pinus virginiana & Scrub pine \\
\hline Pinus taeda & Loblolly pine \\
\hline Liriodendron tulipifera & Tulip poplar \\
\hline Platamus occidentalis & American sycamore \\
\hline Liquidambar styraciflua & sweetgum \\
\hline Albizia julibrissin & mimosa \\
\hline Juncus coriaceus & Rush \\
\hline Rubus sp. & blackberry \\
\hline Juniperus virginiana & Eastern red cedar \\
\hline Setariasp. & Foxtail \\
\hline Cercis canadensis & Red bud \\
\hline Cormus florida & Flowering dogwood \\
\hline Ulmus alata & Winged elm \\
\hline Rhus copallina & Winged sumac \\
\hline Elaeagnus umbellata & Autumn olive \\
\hline Lonicera japonica & Japanese honeysuckle \\
\hline Rhus radicans & Poison ivy \\
\hline Diospyros virginiana & persimmon \\
\hline Anaphalis margaritacea & Pearly everlasting \\
\hline Erechtites hieracifolia & pilewort \\
\hline
\end{tabular}




\begin{tabular}{|ll|}
\hline \multicolumn{1}{|c|}{ Scientific name } & \multicolumn{1}{c|}{ Common name } \\
\hline Sorghum halepense & Johnson grass \\
\hline Solanum carolinense & Horse-nettle \\
\hline Daucus carota & Queen-Anne's lace \\
\hline Ratibada columnifera & Columnar prairie coneflower \\
\hline Solidago nemoralis & Gray goldenrod \\
\hline Solidago gigantea & Tall goldenrod \\
\hline Dioscorea oppositifolia & Air potato \\
\hline Danthonia spicata & Poverty grass \\
\hline Diodia sp. & buttonweed \\
\hline
\end{tabular}


Table C-8. Plant species list for the pond and adjacent areas near Building 9114

\begin{tabular}{|ll|}
\hline \multicolumn{1}{|c|}{ Scientific name } & Common name \\
\hline Acer rubrum & Red maple \\
\hline Liriodendron tulipifera & Tulip poplar \\
\hline Juglans nigra & Black walnut \\
\hline Quercus primus & Chestnut oak \\
\hline Platanus occidentalis & American sycamore \\
\hline Prunus serotina & Black cherry \\
\hline Fraxinus pennsylvanica & Green ash \\
\hline Quercus alba & White oak \\
\hline Ulmus sp. & Elm \\
\hline Morus rubus & Red mulberry \\
\hline Acer saccharum & Sugar maple \\
\hline Juniperus virginiana & Eastern red cedar \\
\hline Cercis canadensis & Red bud \\
\hline Lonicera japonica & Japanese honeysuckle \\
\hline Lonicera maackii & Bush honeysuckle \\
\hline Rosa multiflora & Multiflora rose \\
\hline Ligustrum sinense & Privet \\
\hline Elaeagnus umbellata & Autumn olive \\
\hline Rhus glabra & Smooth sumac \\
\hline Rubus sp. & Blackberry \\
\hline Celastrus orbiculatus & Oriental bittersweet \\
\hline Toxicodendron radicans & Poison ivy \\
\hline Lespedeza cuneata & Sericea lespedeza \\
\hline Solidago caesia & Blue-stemmed goldenrod \\
\hline Microstegium vimineum & Nepal grass \\
\hline Boehmeria cylindrica & False-nettle \\
\hline Leersia oryzoides & Rice cutgrass \\
\hline Polygomum punctatum & Dotted smartweed \\
\hline Gerardia sp. & False foxglove \\
\hline Hepatica & hepatica \\
\hline Chimaphila maculata & Striped pipsissewa \\
\hline
\end{tabular}


Document No.

\section{RP-SH. 801768 .A006 Rev.2 2.25.10}

Unclassified Title

Wetiand and Sensitive Species Survey Report

Author's / Requestor's Name

mick wiest mxy 574.3390 , pager 417.5261

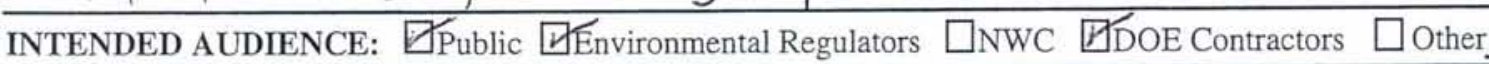

\begin{tabular}{|c|c|c|c|c|c|c|}
\hline TYPE: & $\begin{array}{l}\square \text { Abstract } \\
\square \text { Invention Disclosure } \\
\square \text { Thesis/Term Paper }\end{array}$ & $\begin{array}{l}\square \text { Brochure } \\
\square \text { Journal Article } \\
\square \text { Videotape }\end{array}$ & $\begin{array}{l}\square \text { Co-op Report } \\
\square \text { News Release } \\
\square \text { Other } \\
\end{array}$ & $\begin{array}{l}\square \text { Formal Report } \\
\square \text { Photograph/Visuals }\end{array}$ & $\begin{array}{l}\square \text { Informal Report } \\
\square \text { Technical Progress Report }\end{array}$ & $\begin{array}{l}\square \mathrm{CD} \\
\square \mathrm{DVD}\end{array}$ \\
\hline
\end{tabular}

PATENT OR INVENTION SIGNIFICANCE $\square$ Yes $\square$ KNo (Identify) Document will be published in proceedings $\square$ Yes $\square$ No Document has been previously released $\square$ Yes $\square$ 'No (Reference) Document will be distributed at meeting $\square$ Yes $\square$ No

This document contains unclassified controlled information. $\square$ YES 叉 NO [If yes, please identify below.]
$\square$ Unclassified Controlled Nuclear Information (UCNI)
$\square$ Export Controlled Information
$\square$ Privacy Act Information
$\square$ Copyrighted Information

\author{
$\square$ Intellectual Property Information \\ $\square$ Proprietary Information \\ $\square$ Applied Technology Information \\ $\square$ Other Sensitive Information
}

\author{
$\square$ Internal Use Only \\ $\square$ Official Use Only \\ $\square$ Work For Others or CRADA
}

ORGANIZATION REVIEW AND APPROVAL (Completed by Requesting Organization)

DERIVATIVE CLASSIFIER (DC) REVIEW

TITLE Level $U$ Category $N / A$

ABSTRACT Level $U$ Category N/A

DOCUMENT Level $\frac{U}{S / N / A}$

S.T.Duke Sfarder $2 / 25 / 10$

DOCUMENT REQUEST APPROVED (Organization/Department Mgr.)

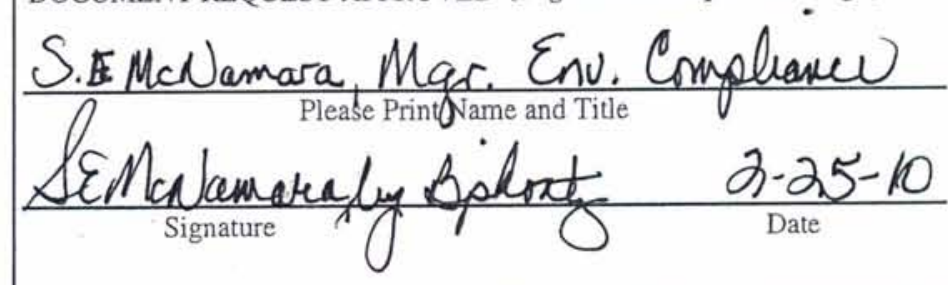

APPROVAL AND RELEASE (Completed by the Classification and Technical Information Office)

\section{CLASSIFICATION OFFICE REVIEW}

TITLE
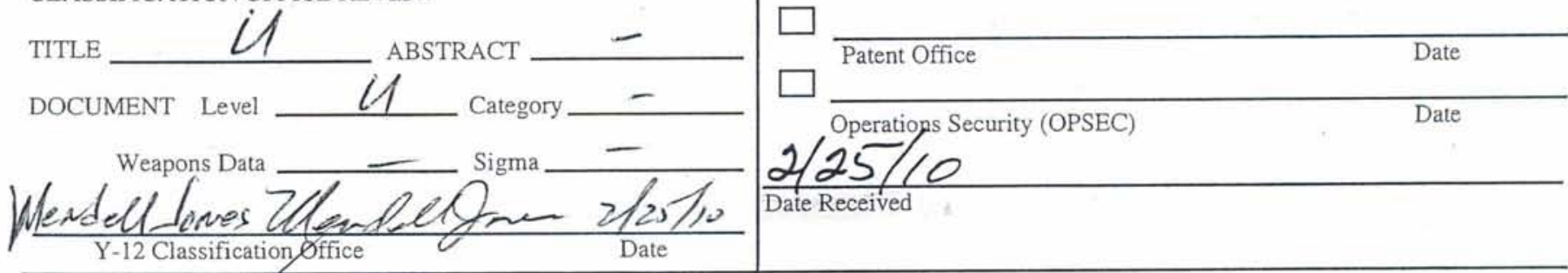

DISTRIBUTION: D UNLIMITED

$\square$ LIMITED

$\square$ SPECIAL LIMITED

D. DOE-OSTI: Distribution Category $U C-202$

$\square$ OTHER

Distribution Remarks:

$\square$ Release subject to use of the following admonitory markings and conditions

$\square$ Disclaimer $\square$ Copyright $\square$ Patent Caution $\square$ Other

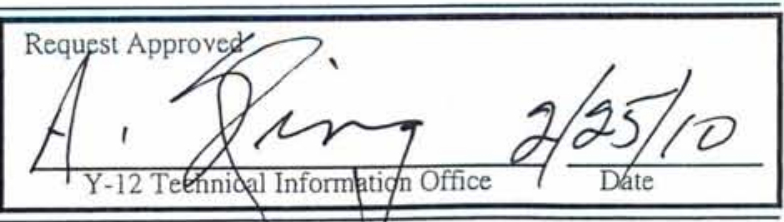

